\title{
The scope for better industry representation in long-term energy models: Modeling the cement industry
}

\author{
Katerina Kermeli $^{\mathrm{a}, *}$, Oreane Y. Edelenbosch ${ }^{\mathrm{b}, \mathrm{c}}$, Wina Crijns-Graus ${ }^{\mathrm{a}}$, Bas J. van Ruijven ${ }^{\mathrm{d}, \mathrm{e}}$, \\ Silvana Mima ${ }^{\mathrm{f}}$, Detlef P. van Vuuren ${ }^{\mathrm{a}, \mathrm{b}}$, Ernst Worrell ${ }^{\mathrm{a}}$ \\ ${ }^{a}$ Copernicus Institute of Sustainable Development, Utrecht University, Princetonlaan 8a, 3584 CB Utrecht, the Netherlands \\ ${ }^{\mathrm{b}}$ PBL Netherlands Environmental Assessment Agency, Bezuidenhoutseweg 30, 2594 AV The Hague, the Netherlands \\ ${ }^{\mathrm{c}}$ Department of Management and Economics, Politecnico di Milano, Piazza Leonardo da Vinci 32, 20133 Milano, Italy \\ ${ }^{\mathrm{d}}$ National Center for Atmospheric Research (NCAR), 1850 Table Mesa Drive, 80305 Boulder, CO, USA \\ e International Institute for Applied Systems Analysis (IIASA), Schlossplatz 1, A-2361 Laxenburg, Austria \\ ${ }^{\mathrm{f}}$ GAEL, CNRS, Grenoble INP, INRA, Université Grenoble-Alpes, 38400 Saint Martin d'Hères, France
}

\section{H I G H L I G H T S}

- The paper illustrates the importance of capturing cross-sectoral relationships between industries in IAMs.

- Retrofitting and clinker to cement ratio is not sufficiently represented in IAMs.

- Retrofitting can offer considerable energy savings in the short-term.

- Reducing the clinker content in cement can offer significant energy savings.

- Limited future fly ash availability reduces the potential for clinker substitution.

\section{A R T I C L E I N F O}

\section{Keywords:}

Integrated Assessment Models

Cement industry

Energy efficiency

Clinker to cement ratio

Retrofitting

Supplementary cementitious materials

\begin{abstract}
A B S T R A C T
Although the cement industry emits around $6 \%$ of global $\mathrm{CO}_{2}$ emissions, most global Integrated Assessment Models (IAMs) barely represent this industrial subsector or do not cover all important processes. This study, describes the state-of-the-art of cement modelling in IAMs, suggests possible improvements and discusses the impacts of these on energy and greenhouse gas emissions (GHG) in the IMAGE global IAM.

It is found that two cement-sector specific GHG mitigation measures are often not explicitly accounted for in IAMs, namely: (i) retrofitting and (ii) reducing the clinker to cement ratio. For retrofitting, many measures are identified as cost-effective and when incorporating these in the IMAGE model overall energy use reduces between 2010 and 2035 by 9.8 and 11 EJ (4\% and 5\%) under the baseline and GHG mitigation scenarios, respectively. When incorporating the clinker to cement ratio by linking material availability to the activities in the steel industry and coal-fired power plants, the 2050 energy use reduces by $15 \%$ under the baseline scenario and increases by $9 \%$ under the GHG mitigation scenario as fewer coal-fired power plants are in operation. This is even more prominent in the long term. The 2100 energy use is $14 \%$ higher in the GHG mitigation scenario as even fewer coal-fired power plants are used drastically limiting the potential for clinker substitution with fly ash. These results highlight the importance of capturing cross-sectoral relationships between industries and of including sector specific mitigation measures in long-term energy models.
\end{abstract}

\section{Introduction}

In 2014, the global industrial sector consumed $154 \mathrm{EJ}^{1}$ and emitted
$8.3 \mathrm{GtCO}_{2},{ }^{2}$ being responsible for $36 \%$ of global energy consumption and about $24 \%$ of direct $\mathrm{CO}_{2}$ emissions [1]. The International Energy Agency (IEA) [2] projects that without any further actions taken, by

\footnotetext{
* Corresponding author.

E-mail address: a.kermeli@uu.nl (K. Kermeli).

${ }^{1}$ Including energy use in blast furnaces and coke ovens in the steel industry, energy use as feedstock (25 EJ in the chemical and petrochemical industry) and industry own use.

${ }^{2}$ Does not include indirect $\mathrm{CO}_{2}$ emissions for electricity generation.
} 
2040, industrial energy use will reach $171 \mathrm{EJ}$ and $\mathrm{CO}_{2}$ emissions will amount to $15 \mathrm{GtCO}_{2}$ (still around a third of energy use and emissions).

Energy models, such as those included in Integrated Assessment Models (IAMs), are used to project global energy use and greenhouse gas emissions (GHGs) and to analyze the potentials and the associated costs of several energy and GHG mitigation options. Major international assessments such as the Intergovernmental Panel of Climate Change (IPCC) special reports [3], and the Global Energy Assessment (GEA) [4], for instance, rely heavily on the scenarios produced by IAMs. Due to their global and economy-wide scope, the level of detail in the industry modules of many IAMs is often not detailed enough to allow for sector specific technology representation $[5,6]$, with many of the IAMs assessing the industry in an aggregated manner without sub-sector division [7]. Still, making good estimates of the short and long-term energy and GHG reduction potentials and associated costs, and understanding the material demand and resource availability and their impact on energy use is very important when evaluating mitigation strategies and developing industry specific policies.

In an effort to understand and potentially improve the way the industrial sector is modelled in IAMs, we focus this analysis on the cement industry. Main two reasons for choosing this industrial sub-sector are (i) high GHG emissions and (ii) limited complexity. In 2014, the cement industry consumed 10.6 EJ of energy ( $7 \%$ of industrial energy use). Due to the high level of process emissions, cement production comprises the second largest industrial emitter, following the iron and steel industry, accounting for $27 \%$ (2.2 $\mathrm{GtCO}_{2}$ in 2014) of industrial emissions and $6 \%{ }^{3}$ of global $\mathrm{CO}_{2}$ emissions [1]. The cement industry comprises an industry with little complexity and can therefore be easier incorporated in existing IAMs than other industrial sub-sectors. Its limited complexity is due to a number of factors. Most cement is consumed in a single sector: the construction sector. Therefore, cement consumption could be linked to construction activity. In addition, trade is limited as cement is mainly consumed in the country of production. Moreover, the cement manufacturing process is common to all cement plants (although the raw materials or additives vary between countries).

Comparison studies of industrial representation in long-term energy models [7] and more technology detailed IAMs [8] have shown that the two industries most usually included are the cement and the iron and steel industries with several models including technological details [9]. The cement industry although easier to incorporate in models, many IAMs model it as part of the non-metallics minerals sector or do not model it at all [7].

Increasing the level of detail can raise practical issues such as the need for larger computational requirements and expertise needs for operating the model. Except for these practical issues, higher detail in models made for long-term global projections could constrain the model too much with detailed knowledge on current technologies [10]. Still, over the last few years, some models have started to add more technology detail on end-use sectors, including the industry sub-sectors, for the advantages described above. Few long-term energy models have a module with bottom-up details that specifically targets the cement industry. IMAGE, a global integrated assessment model, has an embedded module dedicated to the cement industry used to analyze future projections on energy use and GHG emissions [11]. It covers global and regional clinker and cement demand and production that take into account trade of both materials, choice of production technologies, stock turnover and energy use and GHG emissions. Another example is POLES, which has the option to project regional energy use and $\mathrm{CO}_{2}$ emissions while taking into account production technologies, stock turnover and retrofitting [12].

In this paper, we investigate the scope for adding further bottom-up

\footnotetext{
${ }^{3}$ In 2014, global $\mathrm{CO}_{2}$ emissions from fuel combustion amounted to 32.2 $\mathrm{GtCO}_{2}$ and industrial process $\mathrm{CO}_{2}$ emissions to $2.0 \mathrm{GtCO}_{2}$. The cement industry was responsible for $70 \%$ of total process emissions [1].
}

details to long-term IAMs. We do this by adding more detailed information to a single example model, i.e. the IMAGE model and we look into the question whether similar improvements can also be made to other models. For the less detailed models, that do not model the cement industry or they model it in a more aggregated manner, a set of guidelines for modeling the cement industry were developed. The guidelines can be found in Appendix B.

This paper is structured as follows. In Section 2 we discuss the current representation of the cement industry in long-term models. In Section 3, we provide information from bottom-up analysis that could be used to improve the representation in IAMs. In Section 4, we implement these improvements in IMAGE and present their impact on both global and regional model results covering in this way both industrialized and developing countries and emerging economies. Finally in Section 5, we discuss our results and draw the main conclusions.

\section{Representation of the cement industry in long-term energy models}

Different models are used for long-term energy sector explorations. In the literature, models are referred to as Integrated Assessment Models (IAMs) if they include a wider representation of the economy and earth systems details and to energy system models if they don't. Here, however, we refer to all of them as long-term energy models. Based on the information collected in the EU-FP7 ADVANCE project ${ }^{4}$ (see also [7]). Table 1 provides a brief overview of the representation of cement industry in these models.

Most models treat the non-metallics minerals sector as a whole (Table 1). Out of the eight long-term energy models, only DNE $21+$ and IMAGE explicitly model the cement industry, while Imaclim-R and MESSAGE do not have a representation of the cement industry or the non-metallic minerals sector. POLES models the non-metallic minerals sector but also has a technologically detailed cement module that can be activated on demand. Although the cement industry accounts for most of the energy use in the non-metallics sector, about $70-80 \%$ based on IEA [13], the non-metallics sector includes the production of a variety of materials such as glass, lime, bricks and tiles which are produced with different processes; industrial sub-sectors that in general have different characteristics.

As shown in Edelenbosch et al. [7], baseline scenario projections of global material production (clinker, cement or non-metallic minerals), energy use and energy intensity (GJ/tonne) differ quite significantly among long-term energy models. Constructing a baseline scenario that can well represent the industrial sub-sector by taking into account specific industry characteristics is key in making reliable GHG abatement estimates.

While several large scale global models represent industry sectors energy use on the basis of their economic activity, here we concentrate on those that also represent physical demand of cement (e.g. in tonnes) and therefore can be directly coupled to bottom-up information. Most models that simulate the physical demand are based on historically observed correlations between economic activity and material intensity. In Akashi et al. [14] the GDP and industrial value added are used to forecast steel and cement demand, in Anand et al. [15] cement demand increases with the population and GDP growth and in Pardo et al. [16] where the European cement demand is linked to the GDP per capita evolution. In general, economic activity which is represented by GDP per capita and material intensity, defined as material used per unit of GDP, is analyzed to derive the correlation parameters of an inverted U-shaped curve with the curve depicting the material needs of an economy in different economic phases [17].

Table 2 shows the demand drivers and key modeling parameters in

\footnotetext{
${ }^{4}$ European Union Seventh Framework Programme FP7/2007-2013 ADVANCE project: http://www.fp7-advance.eu/.
} 
Table 1

Main characteristics of models participating in survey [7].

\begin{tabular}{|c|c|c|c|}
\hline Model & Model type & Disaggregation of the industrial sector & Separate modeling of the cement industry \\
\hline AIM-CGE ${ }^{1}$ & CGE & Yes & No (non-metallic minerals) \\
\hline DNE $21+$ & Energy system model & Yes & Yes \\
\hline GCAM & Hybrid/IAM & Yes & No (non-metallic minerals) \\
\hline IMAGE & Hybrid/IAM & Yes & Yes \\
\hline POLES & Energy system model & Yes & No (non-metallic minerals) ${ }^{2}$ \\
\hline TIAM-UCL & IAM based on bottom-up energy model & Yes & No (non-metallic minerals) \\
\hline Imaclim-R & Hybrid CGE with sectoral bottom-up modules & $\mathrm{No}^{3}$ & No \\
\hline MESSAGE & IAM based on bottom-up energy model & No & $\mathrm{No}^{4}$ \\
\hline
\end{tabular}

1 Note that the AIM/Enduse model has a detailed industrial representation, but we selected AIM/CGE since we focus on (IAMs or CGEs) that try to capture interactions between more systems (e.g., the energy and natural earth system).

2 There is detailed cement module also available (see for details JRC/IPTS, [12]).

3 Industries are divided into energy-intensive and non-energy intensive.

${ }^{4}$ Only process $\mathrm{CO}_{2}$ emissions from clinker burning are modeled.

the six models that have a representation of the non-metallic minerals or cement industry. POLES, DNE $21+$, IMAGE, and TIAM-UCL relate the material demand to economic drivers. Some of the models that do not explicitly model physical demand of the cement industry start with directly estimating the energy demand of the sector using production functions. Different types of production functions are used in models assessing climate policies with varying elasticities of substitution [18]. In this type of modeling, energy efficiency is typically represented by the substitution between capital, material, labor and energy inputs.

After the cement demand is determined, an energy intensity value (i.e. as GJ/tonne cement) is usually used to estimate energy demand of the sector. The energy intensity can be based on the type of production technologies used and other important parameters such as the clinker content in cement while in other models an average value is used. Production technologies are represented in four models and retrofitting technologies in two models. In addition, the more efficient use of materials is only taken into consideration by one model explicitly (see Table 2). Modeling the physical demand instead of the energy demand allows for the inclusion of several industry characteristics such as explicit technology representation, material efficiency, retrofitting options therefore allowing for better understanding how sector specific policies can contribute to mitigation.

\section{Information as input to long-term models}

\subsection{Areas of modeling improvements}

Based on the overview of the current state of cement industry representation (Section 2), we identify several areas where bottom-up information could be used for long-term energy modeling:

- modeling cement demand instead of directly modeling the energy demand;

- disaggregating the non-metallics sector to increasing the inclusion of bottom-up information on production technologies on a regional level;

- accounting for material efficiency ${ }^{5}$ in the form of reduced clinker to cement ratio;

- retrofit options.

While the modelling guide in the Appendix B describes methods to

\footnotetext{
${ }^{5}$ Material efficiency in cement making would in principle also include feedstock changes that could reduce emissions (e.g. by replacing limestone with steel slag, blast furnace slag, fly ash, and kiln dust, or by using less limestone) [19] and by reducing cement and/or concrete in applications [20]. In this analysis we focus only on product changes that can reduce emissions (i.e. production of blended cements were clinker is replaced by other materials).
}

develop a basic cement model which includes projecting cement demand and production technology information (the first two suggested improvements), here we focus on (i) retrofitting with energy efficiency measures and (ii) reducing the clinker content in cements based on the availability of supplementary materials. Improvements in energy efficiency can significantly decrease the industry's GHG emissions but in order to develop efficient climate policies, understanding how this energy efficiency can be achieved is crucial. Boyd and Zhang [21] have shown in their analysis of the U.S. cement industry that two mechanisms play a role. Besides the energy efficiency gains from stock turnover (the replacement of old equipment with new which is usually more efficient), there are also significant energy efficiency gains from retrofitting. As different policies can encourage different energy efficiency improvements, energy models should be able to correctly simulate the decision making behavior when it comes to new equipment purchases or the retrofitting of older technologies [22].

- Retrofitting. Industrial equipment's period of use can exceed its originally intended lifetime.. This is a crucial point as prolonging the use of outdated and inefficient equipment affects future trajectories and burns on the carbon budget. Retrofitting in this case will have an important role.

- Reducing clinker content. The clinker content in cement and its contribution to GHG mitigation is a key parameter often overlooked by many long-term energy models (see Table 2). As clinker production is responsible for the majority of energy consumption and $\mathrm{CO}_{2}$ emissions, limiting the volumes of clinker produced by replacing clinker in cement with other cementitious materials, mostly byproducts of the steel industry and coal-fired power plants, is a very efficient way to reduce the industry's environmental impact. How much steel will be produced in the future from primary iron and how much coal will be used for electricity generation will influence the availability of these materials and thereby the cement industry's emissions. Long-term energy models should be able to capture the relationship between the activities in other sectors with the potential environmental performance of the cement industry under different scenarios.

In the following two sections we discuss the option of retrofitting (Section 3.1.1) and clinker to cement ratio modelling (Section 3.1.2) in more detail.

\subsubsection{Retrofitting}

There are many technologies/measures that could be adopted by existing cement plants to reduce the energy use and $\mathrm{CO}_{2}$ emissions (for details see [19]). For a summary of the measures see Table 10 in Appendix A. The readily available information on the related investment costs, lifetimes and potentials for energy savings per technology/ measure can allow for the incorporation of retrofitting in energy 
models. The only additional parameter that needs to be defined is the implementation rate. The approach we followed to estimate the implementation rate per measure and per region is the following:

First, based on information on the main technologies used for clinker production per region (see Table 3), we determined the regional implementation rates of the main retrofitting technologies (i.e., "Conversion of long dry to preheater", "Addition of precalciner or upgrade", "Conversion of long dry to preheater precalciner", "Conversion from wet to dry precalciner" and "Conversion from semi-wet to semi-dry to dry precalciner").

Second, to determine implementation rates of the remaining technologies, for which there is limited information on current adoption rates, we compared the fuel intensity of Best Available Technology (BAT) with the current energy intensity in each region (seen in Fig. 1) and calculated the technical energy savings potential for the base year. We then estimated the energy savings in each region, based on the implementation rates of the five main technologies listed in the previous paragraph and the typical energy savings they can offer (see Table 10 in Appendix A). We then deducted these energy savings from the technical energy savings potential to estimate the remaining energy savings potential that can be achieved with technologies other than the main five. The implementation rates for each of these technologies are estimated based on expert knowledge from industry. Table 11 in Appendix A shows the estimated implementation rates per technology and per region for 2010 .

Table 4 shows the estimated energy savings per technology and per region along with the Cost of Conserved Energy (CCE) for a high discount rate of $30 \%$ used to reflect the private perspective. As shown, most measures can be cost-effective (CCE $<$ energy price) in most countries. $^{6}$

\subsubsection{Clinker to cement ratio}

Portland cement has a clinker to cement ratio of $95-100 \%$ (the remaining part is gypsum). Substituting a part of clinker with other materials with similar properties (hydraulic and/or pozzolanic) reduces the clinker content in cement lowering the demand for clinker. Reducing clinker production by 1 tonne will roughly reduce $\mathrm{CO}_{2}$ emissions by the same amount. Cements that contain clinker substituting materials in considerable quantities are known as blended cements. These materials are either interground with clinker in the final step of cement making ${ }^{7}$ or are ground and dried separately before being mixed with clinker. Estimations on the availability of Supplementary Cementitious Materials (SCMs) are shown in Table 6.

Materials widely used to replace clinker are:

- Granulated Blast Furnace Slag (GBFS). Blast furnace slag (BFS) is a by-product of the iron steel industry. It is formed when iron ore is reduced in blast furnaces to produce pig iron (molten iron). For every tonne of pig iron produced $0.25-0.30 \mathrm{~kg}$ of BFS are formed [24]. BFS can be distinguished based on the cooling method used into granulated, air-cooled and pelletized. When finely ground, ground granulated blast furnace slag (GGBFS) develops strong hydraulic cementitious properties [24], therefore suitable as clinker replacement in blended cements. Air-cooled blast furnace slag (ACBFS) on the other hand, is not suitable for use in cements and is mainly used as an aggregate in construction activities. Pelletized slag is usually used as lightweight aggregate but when finely ground can have similar cementitious properties to GGBFS [25]. About $75 \%$ of world BFS production is currently granulated [26]. It is estimated that in 2014, BFS production amounted to 325 Mtonnes (see

\footnotetext{
${ }^{6}$ In 2017, the median IEA price of industrial natural gas was $\$ 6.3 / \mathrm{GJ}$ [23].

${ }^{7}$ These substitutes can either be used to replace clinker in the cement or the concrete mix (product change) or can be introduced in the kiln feed (feedstock change) to replace limestone.
} 
Table 3

Kiln technologies used in the different regions in 2013 [43].

\begin{tabular}{|c|c|c|c|c|c|}
\hline & $\begin{array}{l}\text { Dry with preheater and } \\
\text { precalciner }\end{array}$ & $\begin{array}{l}\text { Dry with preheater without } \\
\text { precalciner }\end{array}$ & $\begin{array}{l}\text { Dry without preheater (long } \\
\text { dry) }\end{array}$ & $\begin{array}{l}\text { Semi wet/semi } \\
\text { dry }\end{array}$ & Wet/shaft kilns \\
\hline Europe $^{1}$ & $48 \%$ & $29 \%$ & $10 \%$ & $8 \%$ & $6 \%$ \\
\hline Africa & $82 \%$ & $11 \%$ & $2 \%$ & $0 \%$ & $4 \%$ \\
\hline $\begin{array}{l}\text { Asia \& Oceania (excl. China, India and } \\
\quad \text { CIS) }\end{array}$ & $91 \%$ & $9 \%$ & $0 \%$ & $0 \%$ & $0 \%$ \\
\hline Brazil & $100 \%$ & $0 \%$ & $0 \%$ & $0 \%$ & $0 \%$ \\
\hline Central America & $69 \%$ & $31 \%$ & $0 \%$ & $0 \%$ & $0 \%$ \\
\hline China $^{2}$ & $90 \%$ & $0 \%$ & $0 \%$ & $0 \%$ & $10 \%$ \\
\hline CIS $^{3}$ & $4 \%$ & $4 \%$ & $4 \%$ & $3 \%$ & $85 \%$ \\
\hline Middle East & $88 \%$ & $12 \%$ & $0 \%$ & $0 \%$ & $0 \%$ \\
\hline North America & $61 \%$ & $18 \%$ & $12 \%$ & $0 \%$ & $9 \%$ \\
\hline South America (excl. Brazil) & $67 \%$ & $33 \%$ & $0 \%$ & $0 \%$ & $0 \%$ \\
\hline India & $100 \%$ & $0 \%$ & $0 \%$ & $0 \%$ & $0 \%$ \\
\hline
\end{tabular}

1 Assumed the same shares with EU28 reported in WBCSD [43].

2 Ref. [51].

3 Year 2005 [52]. In 2005, the dry kiln technology accounted for $12 \%$ of clinker production in 2005. Due to the lack of more detailed data, this share was split equally between the three different technologies shown in this table.

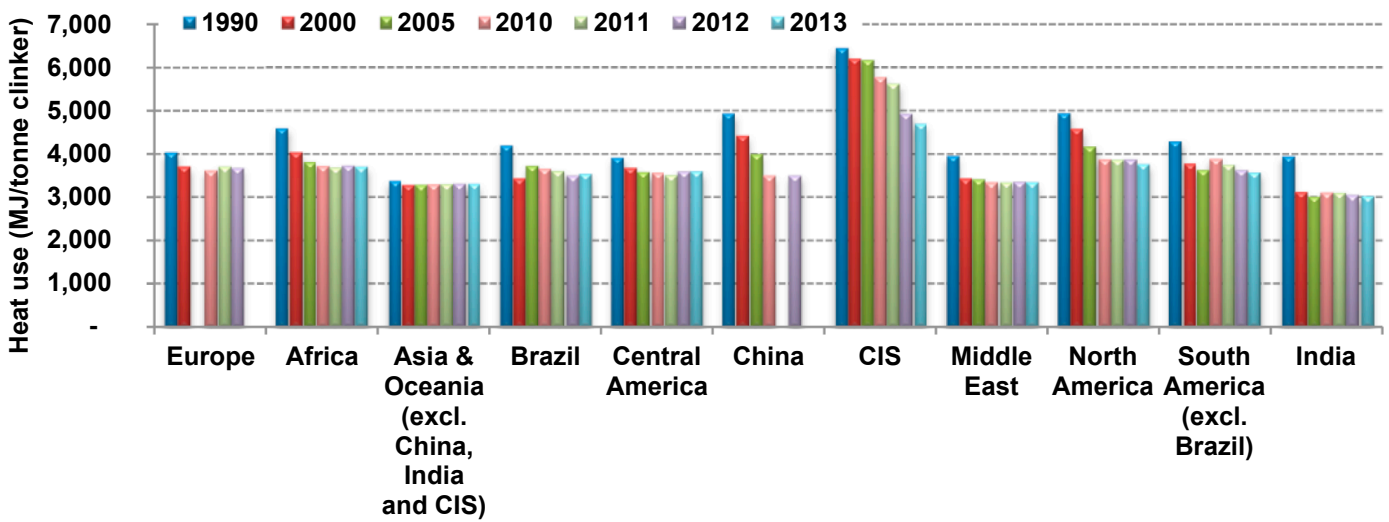

Fig. 1. Heat consumption for clinker making per region $[43,44]$. Heat use for fuel drying is not included.

Table 6). The BFS cements can contain up to 95\% slags [27], however technically (current practice) the content ranges between 30 and $70 \%$ [28].

It has been shown that a large part of future steel demand could be covered by recovering the steel currently accumulated in steel products (old scrap) and from manufacturing processes (new scrap). Oda et al. [29] estimate that by 2050 about $40 \%$ of steel will be produced with the secondary route. Pauliuk et al. [30] estimate that after 2050 secondary steel production will exceed primary steel production and could account for more than $60 \%$ by 2100 . This would result in lower reliance on steel production from iron with the use of blast furnaces and could thereby limit BFS generation.

- Fly ash. Fly ash is generated when coal is burned in furnaces. Fly ash can be of (i) siliceous (silica-rich) or (ii) calcareous (lime-rich) nature and has pozzolanic properties [28]. Calcareous fly ash may also have hydraulic properties. In Europe, because calcareous fly ashes can have strong variations in chemical composition and high sulfate content, the fly ash mostly used is of siliceous nature. Siliceous fly ash is generated in hard coal-fired power plants [31] (i.e. bituminous and anthracite coal). Not all fly ash can be used in cement production [32]. For both siliceous and calcareous fly ash certain criteria need to be met.

The amounts of fly ash generated depend on the coal quality and the technologies in place. For every tonne of coal burnt 0.08-0.30 tonnes of fly ash are generated. Table 5 shows our estimates of the fly ash production in a number of regions/countries.

Fly ash cements can have a fly ash content of 6-55\% (siliceous). In technically used cements the fly ash content is in the range of $25-35 \%$ [28].

The efforts made to decarbonize the electricity sector and the future heavy reliance on renewable sources of energy will reduce fly ash availability and thereby the potential for use as clinker substitute.

- Pozzolanas. Pozzolanas are materials of mainly siliceous nature that can either occur naturally or be developed artificially. Natural pozzolanas are materials of volcanic origin or sedimentary rocks such as pumice and pumicite. The world production in 2013 of pumice and other natural pozzolanas was estimated at 18.6 Mtonnes [33]. Artificial pozzolanas, or else known as calcined natural pozzolanas, are materials with pozzolanic properties that need to be calcined in kilns. Some examples are calcined clays, calcined shale and metakaolin [34]. The global production of artificial pozzolanas is hard to estimate. Other materials with pozzolanic properties are rice husk ash and silica fume. Rice husk is a byproduct of the rice industry commonly burnt or discarded as waste [35]. It is estimated that in 2014 about 10 Mtonnes of rice husk were produced, with which 27 Mtonnes of ash could be generated. Silica fume is a silicarich byproduct of the silicon alloy production industry available only in limited quantities.

According to the European standard EN 197-1, cements containing $6-55 \%$ pozzolanas are possible; however in currently used cements the mass content is limited to $15-35 \%$ [28]. For pozzolanas that do not 
Table 5

Estimated fly ash production in the different world regions in 2011.

\begin{tabular}{llll}
\hline $\begin{array}{l}\text { Country/ } \\
\text { region }\end{array}$ & $\begin{array}{l}\text { Coal consumption for } \\
\text { el. generation } \\
\text { Mtonnes }^{2}\end{array}$ & $\begin{array}{l}\text { Fly ash content in } \\
\text { coal (tonne fly } \\
\text { ash/tonne coal) }\end{array}$ & $\begin{array}{l}\text { Fly ash } \\
\text { production } \\
\text { (Mtonnes) }\end{array}$ \\
\hline Australia & 89 & 0.13 & $11.8^{1}$ \\
Canada & $41^{4}$ & $0.08^{3}$ & 3.4 \\
China & 1551 & $0.28^{5}$ & 429.6 \\
Europe (15) & 224 & $0.16^{6}$ & 35.4 \\
India & 400 & $0.27^{7}$ & 107.3 \\
Japan & 90 & $0.11^{8}$ & 9.9 \\
United States & $639^{9}$ & 0.09 & $66.0^{9}$ \\
Russia & 143 & $0.17^{10}$ & 25.6 \\
Brazil & 6 & $0.37^{11}$ & 2.1 \\
Total & 3477 & 0.20 (average) & 691 \\
Rest (23\% of & 988 & 0.20 (average) & 196 \\
$\quad$ coal use) & & & \\
World & 4465 & 0.20 (average) & 887 \\
\hline
\end{tabular}

1 Ref. [53].

2 Unless otherwise mentioned, the volumes of coal consumed for electricity generation were estimated based on the coal use (in ktoe) reported in IEA statistics [54] and the typical gross calorific values (GCV) of each coal type [55].

3 In 2006, Canadian power plants consumed about 51 Mtonnes of coal [56] and generated 4.2 Mtonnes of fly ash [57].

4 Ref. [56].

5 Chinese coal is characterized by high fly ash content that ranges between 0.25 and 0.3 tonnes/tonne coal [58]. Typically Flue Gas Desulphurization Gypsum (FGD) produced during sulfur removal is not considered to be fly ash. However that is the case in the Lan and Yuansheng [58] analysis. To exclude FGD (primarily used in the production of gypsum) we subtract the 76.6 Mtonnes of FGD that was produced in coal-fired power plants in 2011 [59].

6 In 2003, 44.1 Mtonnes of fly ash were generated in EU (15) [60]. Based on the IEA statistics [54], it is estimated that in 2003, 279 Mtonnes of coal were consumed for power generation. That leads to a factor of 0.16 tonnes of fly ash per tonne of coal consumed in coal-fired plants.

7 In 2014/15, coal consumption in Indian coal-fired power plants reached 437 Mtonnes and coal ash production 145 Mtonnes (a 33.2\% ash content) [61]. This also includes bottom ash that accounts for about $20 \%$ of ash production [62] resulting in about $27 \%$ fly ash content. This is in agreement with the annual volumes reported in other studies $[63,64]$.

8 In 2007, Japan generated 12 Mtonnes of coal ash [65]. In Japan, 90\% of coal ash generated is fly ash [66]. The same year about 98 Mtonnes of coal were consumed in power plants (estimated based on [54]); resulting in a factor of 0.11 .

9 Ref. [67].

10 Average ash content (containing bottom ash) of coal used in Russian power plants is around $21 \%$ [68]. Of which bottom ash usually accounts for $20-25 \%$ [69].

11 According to Moon [65], Brazilian plants consume annually 37 Mtonnes of coal and generate 17 Mtonnes of fly and bottom ash. Usually bottom ash accounts for $20-25 \%$ of total ash production. We therefore estimate a fly ash content of 0.37 .

require calcination the decrease in energy use and $\mathrm{CO}_{2}$ emissions from clinker replacement is almost linear to the increase in pozzolana use. If artificial pozzolanas are used the energy use from pozzolana calcination and the associated $\mathrm{CO}_{2}$ emissions must be taken into account.

- Limestone. Another way to reduce the clinker content in cements is by adding limestone. Limestone is widely available to cement plants as it is the main raw material used in cement production. Limestone is typically used in cements as a minor constituent (up to 5\%) for increased workability. Higher limestone quantities however could also be used. The limestone content in cement could be as high as 25-35\% [28]. For limestone cements to show similar strengths with ordinary Portland cement (OPC) the particle fineness needs to increase. The properties of limestone cements with up to $15 \%$ limestone content can be compared to OPC [36]. 
Table 6

Estimated annual production of supplementary cementitious materials.

\begin{tabular}{|c|c|c|}
\hline Supplementary Cementitious Materials (SCMs) & Estimated Annual Production (Mtonnes) & Production factor \\
\hline Blast Furnace Slag ${ }^{1}$ & $296-355$ (in 2014) & $\begin{array}{l}0.25-0.30 \mathrm{~kg} \text { BFS/tonne pig iron (USGS, } 2003 \text { ); } \\
0.275 \mathrm{~kg} \mathrm{BFS} / \text { tonne crude steel produced with the } \mathrm{BF} / \mathrm{BOF} \text { route [70] }\end{array}$ \\
\hline Granulated BFS & $222-266$ & - \\
\hline $\begin{array}{l}\text { Fly } \text { Ash }^{3} \\
\text { Hard coal fly ash }\end{array}$ & $\begin{array}{l}720-865 \text { (in 2012) } \\
570-690 \text { (in 2012) }\end{array}$ & $\begin{array}{l}\text { depends on coal quality (see Table 5) } \\
\text { - }\end{array}$ \\
\hline Natural Pozzolanas & 18.6 (in 2013) & \\
\hline Volcanic ash & 0.5 & - \\
\hline Pumice & 2.9 & - \\
\hline Pozzolanas & 6.6 & - \\
\hline Unspecified & 8.6 & - \\
\hline Artificial Pozzolanas & N/A & - \\
\hline Other Pozzolanas & $\sim 42.5$ & \\
\hline Rice husk ash & 27 (in 2014) & $5.5 \mathrm{~kg}$ rice husk ash per tonne rice paddy milled [35] \\
\hline Silica fume & $<1.5$ (in 2008) & $0.1-0.25$ tonnes per tonne quartz $[71]$ \\
\hline Total (excl. artificial pozz.) & $862-1050$ & \\
\hline
\end{tabular}

1 BFS production data are not available. The volumes were estimated based on the production factors reported and global pig iron production for 2014 (1183 Mtonnes) (Worldsteel statistics).

${ }^{2}$ Only fly ash generated from coal-fired power plants. Estimated based on coal consumption data for electricity generation reported in 2014 IEA statistics [54] and the average production factor shown in Table 5 .

${ }^{3}$ Fly ash formed in power plants using anthracite and bituminous coal.

\subsection{Modeling approach}

\subsubsection{Accounting for retrofitting}

In the following paragraphs we present three ways for incorporating retrofitting in energy models.

(i) Cost-supply curves.

Cost-supply curves are a useful tool that is used to present the costeffective as well as the technical energy and GHG savings potentials of several energy efficiency measures. To construct the curves, the energy and GHG emission mitigating measures/technologies are ranked based on their Cost of Conserved Energy (CCE), or Cost of Mitigated Greenhouse Gases $\left(\mathrm{C}_{\mathrm{CO} 2-\mathrm{eq}}\right)$. The cost-supply curves show in the y-axis the CCE and in the $\mathrm{x}$-axis the cumulative energy savings and the cumulative GHG emission savings. The width of each segment in the graph shows the energy or GHG savings potential of each energy efficiency improvement measure.

The CCE can be determined with the use of Eqs. Eqs. (1) and (2), respectively.

$C C E=\frac{\text { Annualized investment cost }+ \text { Annual O\&M costs }}{\text { Annual energy savings }}$

The annualized investment cost is a function of the discount rate and the technical lifetime of the technology and can be calculated from Eq. (2).

Annualized investment cost $=$ Investment $\cos t \times \frac{d}{\left(1-(1+d)^{-n}\right)}$

where $d$ is the discount rate and $n$ the technical lifetime of the measure.

Long-term energy models typically estimate future energy prices based on technology development, regional resource availability and trade. Certain measures that are found to be cost-effective in one country/region might not be cost-effective in another due to regional price differences. This effect can be represented by cost-supply curves, where an increase in energy prices due to for example policy measures, will for some measures result in switching from non-cost-effective to cost-effective. In addition, the energy prices for which important energy efficiency measures become cost-effective can be determined.

(ii) Payback period (PBP)
Another way of incorporating technological detail could be by estimating the Payback period (PBP) for every measure. All measures can then be ranked based on their PBP and the measures with the lowest PBP can be implemented first (Eq. (3)).

$P B P=\frac{\text { Initial investment }}{\text { Annual operational benefits }- \text { Annual operational costs }}$

(iii) Step function

The wide range of energy efficiency measures could also be clustered based on the required investments costs into (a) low investment measures, (b) medium investment measures, and (c) high investment measures. The model can then use a step function and assess the reduction in energy consumption.

In addition, the measures could be clustered in the measures for each key process; i.e. clinker and cement making. Low investment measures are measures that will typically have a PBP of less than 3 years, medium investment measures are measures with a PBP of 3-5 years and high investment measures are measures with a PBP higher than 5 years. All approaches should take into account the potentials for technology implementation in each region (see Table 11 in Appendix A).

\subsubsection{Endogenously determining the clinker to cement ratio}

By linking the availability of key SCMs to the output of other sector modules within the model, the clinker to cement ratio could be modeled endogenously. More specifically, for long-term energy models that model steel production and electricity production from coal-fired power plants process explicitly, the availability of GBFS can be linked to primary steel production and the availability of fly ash to the activity of coal-fired power plants.

A simplified way to estimate the potential for energy savings and GHG abatement that an increased use of clinker substituting materials could achieve, can be to only consider the availability of the main raw materials. In this way, the relationship between the activity of the main SCM sources and the cement industry are captured. In reality, the development of the clinker content in cement in the various world regions can be very hard to forecast, as the use of SCMs does not depend only on their availability but also on a number of other important parameters [28], (i) prices of clinker substitutes, (ii) national standards, (iii) market acceptance and (iv) cement properties. 
Modelling using the above described approach does give an approximation of the technical potential. This assumes that the cement industry consumes all available clinker substituting materials under the restrictions that:

- Blast Furnace Slag (BFS) cement can contain up to 65\% BFS;

- Fly Ash cement can contain up to $35 \%$ fly ash;

- Limestone cement can contain up to $15 \%$ limestone;

- Blended cements cannot contain more than one clinker substituting material.

Because the actual availability/reserves of pozzolanas is/are hard to quantify we do not consider pozzolana cement production in this study. In addition, we do not allow for the production of blended cements that contain more than one type of clinker substituting materials. This is because it would be hard to restrict the levels of the different materials that could be used for a widely acceptable cement quality.

To determine the shares of the different cement types in an effort to estimate the clinker production for each region if all available clinker substitutes are consumed we follow the following allocation approach:

First, we determine the potential for BFS cement production based on the generation of BFS from steel plants operating blast furnaces under the restriction that BFS cement can contain up to $65 \%$ BFS. We then determine the amount of fly ash cement that is generated, with the restrictions that fly ash cement can contain up to $35 \%$ fly ash and that $\mathrm{BFS}$ cement does not contain fly ash. All remaining cement is limestone cement with $15 \%$ limestone. For all cement types we assume that minor constituents account for $5 \%$ of the overall weight. The total production of clinker will be equal to the sum of clinker contained in BFS cement, in fly ash cement and in limestone cement.

$$
\begin{aligned}
P_{\text {clinker }}= & C C_{B F \text { Scement }} * P_{B F \text { Scement }}+C C_{\text {FlyAshcement }} * P_{\text {FlyAshcement }} \\
& +C C_{\text {Limestonecement }} * P_{\text {Limestonecement }}
\end{aligned}
$$

The variable definitions used in this paragraph can be found in Tables 7-9.

Based on the allocation approach described above, Eq. (4) can be rewritten into:

$$
\begin{aligned}
P_{\text {clinker }}= & C C_{B F S c e m e n t} * \frac{C_{B F S}}{B F S . C_{B F S c e m e n t}} \\
& +C C_{\text {FlyAshcement }} * \frac{C_{\text {FlyAsh }}}{\text { FlyAsh. } C_{\text {FlyAshcement }}} \\
& +C C_{\text {Limestonecement }} *\left[P_{\text {cement }}-\frac{C_{B F S}}{B F S . C_{B F S c e m e n t}}\right. \\
& \left.-\frac{C_{\text {FlyAsh }}}{\text { FlyAsh. } C_{\text {FlyAshcement }}}\right]
\end{aligned}
$$

where $\quad P_{B F S c e m e n t}=\frac{C_{B F S}}{B F S . C_{B F S c e m e n t}}, \quad P_{\text {FlyAshcement }}=\frac{C_{F l y A s h}}{\text { FlyAsh.CFlyAshcement }}, \quad$ and $P_{\text {Limestonecement }}=\frac{C_{B F S}}{B F S . C_{B F S c e m e n t}}-\frac{C_{F l y A s h}}{\text { FlyAsh. } C_{F l y A s h c e m e n t}}$.

If $P_{\text {cement }}<P_{B F S} / B F S . C_{B F S c e m e n t}$, then $C_{B F S}=B F S . C_{B F S c e m e n t} / P_{\text {cement }}$

If $P_{\text {cement }}>P_{B F S} / B F S . C_{B F S c e m e n t}$, then $C_{B F S}=P_{B F S}$

where the BFS production $\left(P_{B F S}\right)$ can be calculated with Eq. (7):

$P_{B F S}=P_{\text {steel, total }} *$ Share $_{\text {primaryroute }} * C_{\text {pigiron }} * I_{B F S} * I_{\text {iron }}$

The amount of fly ash consumed in the cement industry $\left(C_{F l y A s h}\right)$ can be calculated with Eq. (8).

$$
\text { If } \begin{aligned}
P_{\text {cement }}-\boldsymbol{P}_{\boldsymbol{B F S c e m e n t}} & <\frac{P_{\text {FlyAsh }}}{\text { FlyAsh. } C_{\text {FlyAshcement }}}, \text { then } C_{\text {FlyAsh }} \\
& =\text { FlyAsh. } C_{\text {FlyAshcement }} *\left(P_{\text {cement }}-\boldsymbol{P}_{\boldsymbol{B F S c e m e n t}}\right)
\end{aligned}
$$

$$
\begin{aligned}
& \text { - If } \quad P_{\text {cement }}-P_{\text {BFScement }}<P_{\text {FlyAsh }} / \text { FlyAsh. } C_{\text {FlyAshcement }}, \\
& C_{\text {FlyAsh }}=P_{\text {FlyAsh }}
\end{aligned}
$$

where $P_{\text {FlyAsh }}$ is given by Eq. (9):

$P_{\text {FlyAsh }}=$ Coal $_{\text {powerplants }} * I_{\text {flyash }}$

\section{Implementation of the bottom-up information in IMAGE}

In this section, we evaluate the model results after the implementation of the two suggested improvements. The section is divided into two parts. The first part shows the impact the inclusion of energy efficiency retrofitting on the model results, while the second part focuses on the impact of the dynamic modeling of the clinker to cement ratio. For the comparison of the cement industry projections, we look into two scenarios:

1. without new climate policies ("baseline scenario") and;

2. aiming at a stabilization level at $450 \mathrm{ppm} \mathrm{CO}_{2}$-eq ("mitigation scenario").

In both cases, we present the data before ("original") and after

\begin{tabular}{|c|c|c|c|}
\hline Parameters & Definition & Unit & Value \\
\hline BFS. $C_{B F S c e m e n t}$ & BFS content in BFS cement & $\%$ & $65 \%$ (fixed value) \\
\hline$C_{B F S}$ & BFS consumed in the cement industry & Mtonnes BFS & Calculated with Eq.6 \\
\hline$C C_{B F S c e m e n t}$ & Clinker content in BFS cement & $\%$ & $30 \%$ (fixed value) \\
\hline CC FlyAshcement & Clinker content in fly ash cement & $\%$ & $60 \%$ (fixed value) \\
\hline CC $C_{\text {Limestonecement }}$ & Clinker content in Limestone cement & $\%$ & $80 \%$ (fixed value) \\
\hline$C_{\text {FlyAsh }}$ & Fly ash consumed in the cement industry & Mtonnes Fly Ash & Calculated with Eq. 8 \\
\hline FlyAsh. $C_{\text {FlyAshcement }}$ & Fly ash content in fly ash cement & $\%$ & $35 \%$ (fixed value) \\
\hline$P_{B F S c e m e n t}$ & BFS cement production & Mtonnes BFS cement & \\
\hline$P_{\text {cement }}$ & Cement production & Mtonnes cement & Model output \\
\hline PFlyAshcement & Fly Ash cement production & Mtonnes Fly Ash cement & \\
\hline Plinker & Clinker production & Mtonnes clinker & \\
\hline$P_{\text {Limestonecement }}$ & Limestone cement production & Mtonnes Limestone cement & \\
\hline
\end{tabular}
("improved") including the improved bottom-up information.

\subsection{Energy efficiency retrofitting}

Previously in IMAGE, when new plants were built either because capacity increased in a specific region or because old plants were decommissioned, the model chose between four technology types ("conventional dry plant", "efficient dry plant", and two technologies of "efficient dry with Carbon Capture and Storage (CCS)"). Although the

Table 7

Variable definitions - Eqs. (4) and (5).

The amount of BFS consumed in the cement industry $\left(C_{B F S}\right)$ can be calculated with Eq. (6). 
Table 8

Variable definitions - Eqs. (6) and (7).

\begin{tabular}{|c|c|c|c|}
\hline Parameter & Definition & Unit & Value \\
\hline$P_{B F S}$ & BFS production & Mtonnes BFS & \\
\hline$P_{\text {steel, } \text { total }}$ & Total steel production & Mtonnes Steel & Model output \\
\hline Share $_{\text {primaryroute }}$ & $\begin{array}{l}\text { The share of steel produced with the primary route (i.e. from iron ore in the blast } \\
\text { furnaces). }\end{array}$ & $\%$ & Model output \\
\hline$C_{\text {pigiron }}$ & The percentage input of pig iron in blast furnaces & $\%$ & Model input (fixed value in IMAGE $=90 \%$ ) \\
\hline$I_{B F S}$ & The amount of BFS generated per tonne of pig iron used in blast furnaces & Tonne BFS/tonne pig iron & 0.275 (fixed value) \\
\hline$I_{\text {iron }}$ & Specific iron requirements per tonne of crude steel generated & Tonne iron/tonne steel & Model input \\
\hline
\end{tabular}

model dealt with stock turnover, it did not deal with energy efficiency improvements in existing cement plants. Based on the method described in Section 3.2.1 using available information on current regional technology adoption levels and on energy savings and investment costs per measure, the model can estimate the impact of retrofitting on the energy consumption. In this way, the "no-regret" measures that are usually not taken into account in energy models are also considered. The scenarios that include retrofitting are named "baseline improved" and "mitigation improved". The "baseline improved" scenario is different from the original baseline, since in that scenario the energy use of existing plants is kept stable during their lifetime. In the "mitigation improved" scenario the same carbon tax is applied that was applied in the original scenario to meet a $450 \mathrm{ppm}$ target.

Fig. 2, shows the projected global fuel use, $\mathrm{CO}_{2}$ emissions, fuel intensity, and regional energy savings before and after taking into account retrofitting. When retrofitting is considered, the energy demand under both scenarios, the baseline and the mitigation scenarios, is lower during the 2010-2040 period. It can be seen that for the upcoming period, there exists a non-negligible potential for energy savings from retrofitting. Overall, the total final energy consumption can be reduced by $9.8 \mathrm{EJ}$ in the baseline improved scenario and by $11 \mathrm{EJ}$ in the mitigation improved scenario. After 2040, retrofitting does not play a role. This is because, no old inefficient plants will be in operation and all new plants that have been added either to cover the increasing cement demand or to replace decommissioned plants were considered in the model to be high efficient state-of-the-art plants. However, if new efficient technologies become available in the future, retrofitting could further reduce the energy use. Emerging/innovative retrofit technologies were not considered in this analysis.

After 2020, the total energy use in the baseline original scenario is projected to phase a gradual increase as a result of the increasing clinker production. Although the global average fuel intensity decreases due to energy efficiency improvements implemented, the absolute energy consumption continues to increase. In 2020, retrofitting can reduce the fuel use for clinker production from 3.2 to $3.0 \mathrm{GJ} /$ tonne clinker in the baseline improved scenario. In the mitigation improved scenario, the fuel intensity drops considerably due to the uptake of innovative energy efficiency technologies that can decrease the energy use to 2.2.GJ/tonne clinker by 2050 . The result is a strong decrease of $\mathrm{CO}_{2}$ emissions which is further enhanced by the decrease in clinker production in the period 2040-2050 (see Fig. 3).

Retrofitting can reduce the total $\mathrm{CO}_{2}$ emissions generated in the period $2010-2040$ by $853 \mathrm{Mt} \mathrm{CO}_{2}$ under the baseline improved scenario and by $917 \mathrm{MtCO}_{2}$ under the mitigation improved scenario (the area between the corresponding lines in the period 2010-2040) (see Fig. 2).
In the "improved" scenarios only energy efficiency improvements considered "cost-effective" are adopted. The highest overall energy savings within the 2010-2040 period are to be found in the China region, Western Europe, Northern Africa and United States amounting to $43.3 \%, 11.3 \%, 5.3 \%$ and $4.1 \%$, respectively. The Russian Federation has a large potential for energy savings from retrofitting as clinker is primarily produced in inefficient wet cement kilns. However, because the measures identified in Table 4 are not found cost-effective (energy prices are low) they are not implemented.

\subsection{Clinker to cement ratio}

In the baseline original scenario, the clinker to cement ratio experiences a modest decrease and from then onwards it gradually decreases to converge to $74 \%$ by 2050 for all regions. Fig. 3 shows the impact that the modeling the clinker to cement ratio based on the method described in Section 3.2.1 has on clinker production, energy demand and $\mathrm{CO}_{2}$ emission projections.

Taking into account the availability of SCMs and the maximum content of SCMs per blended cement type, clinker production can be limited to 2620 Mtonnes in 2050; this is $15 \%$ lower compared to the baseline original scenario (3100 Mtonnes in 2050). After reaching a maximum of 2800 Mtonnes the clinker production decreases to 2600 Mtonnes by 2100 ; about $22 \%$ lower compared to the baseline original scenario. This is due to the high fly ash availability. Fig. 3 also shows the amount of coal consumed for power generation on a global scale in IMAGE. Under the baseline scenario fly ash production is projected to reach 14 Gtonnes by 2100 .

In the mitigation original scenario clinker production is lower than in the baseline original scenario. In the original model formulation in IMAGE, the clinker to cement ratio is modelled dynamically to the carbon price, assuming that climate policy would lead to less clinker use where by 2100 the clinker to cement ratio drops to $65 \%$. However, when taking into account the availability of BFS and fly ash under the same carbon tax (mitigation improved scenario) the clinker to cement ratio is higher due to the limited availability of SCMs. In this scenario the clinker production will reach 3060 Mtonnes in 2050 and 3340 Mtonnes in $2100,9 \%$ and $14 \%$ higher when compared to the mitigation original scenario. This is the result of the decommissioning of many coal-fired plants and the increased use of renewable sources for power generation reducing the generation of fly ash. At the end of the century in the mitigation scenarios, coal consumption for electricity generation drops by $93 \%$, with only about 890 Mtonnes of coal consumed for electricity generation (see Fig. 3). The strong increase of the energy use after 2050 is due to the uptake of CCS that is introduced as a climate

Table 9

Variable definitions - Eqs. (8) and (9).

\begin{tabular}{|c|c|c|c|}
\hline Parameter & Definition & Unit & Value \\
\hline PFlyAsh & Fly ash production from power plants & Mtonnes fly ash & \\
\hline Coal $_{\text {powerplants }}$ & Coal consumption in power plants & Mtonnes coal & Model output \\
\hline$I_{\text {flyash }}$ & The amount of fly ash generated per tonne of coal consumed in power plants & Tonne fly ash/tonne coal & Differs per region (see Table 5) \\
\hline
\end{tabular}



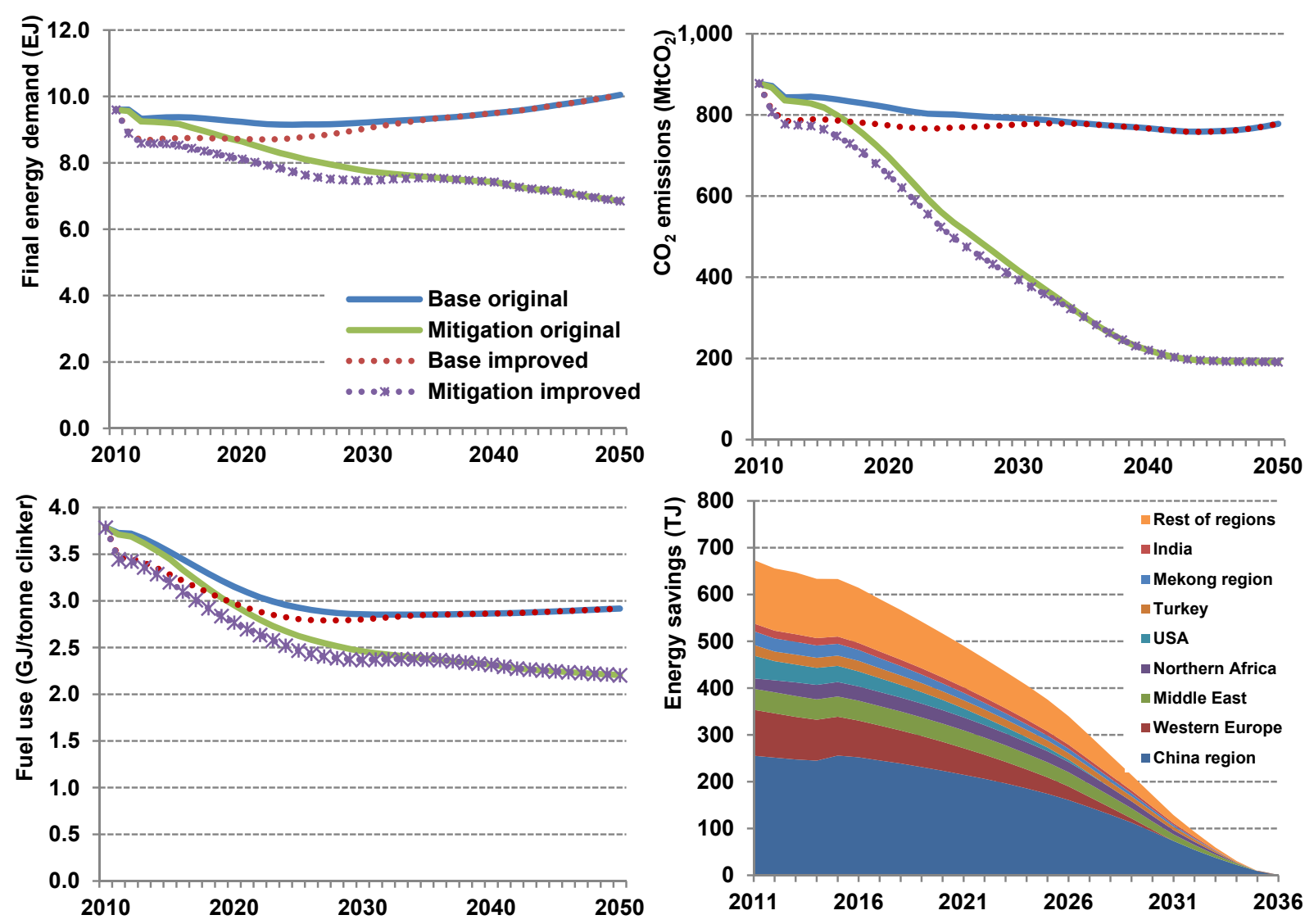

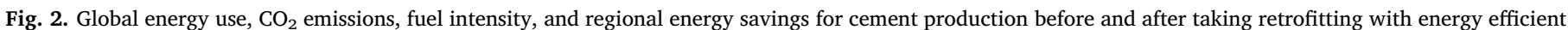
technologies into account under the baseline and mitigation scenario.
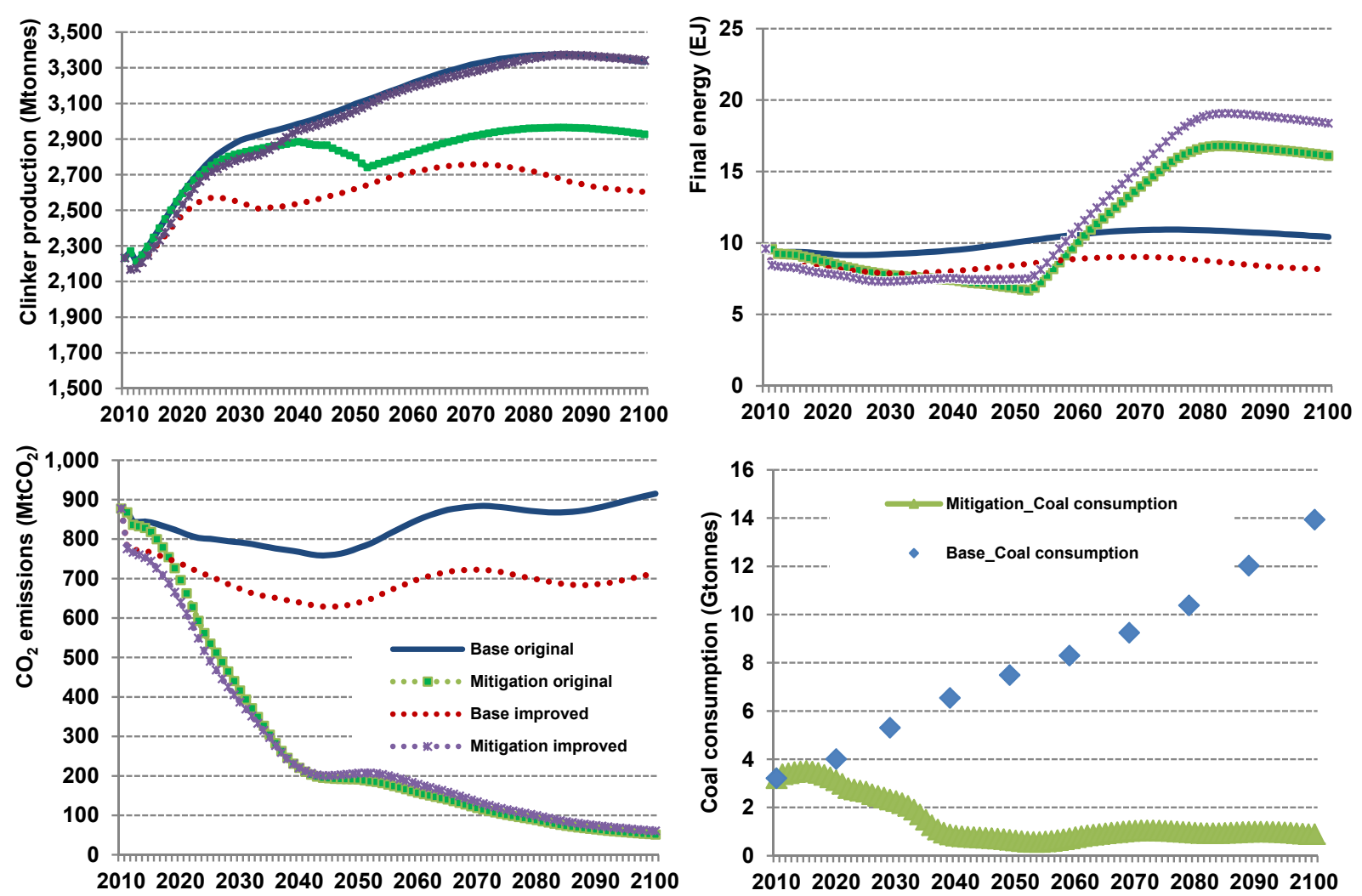

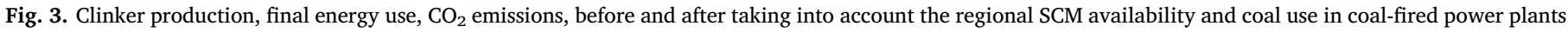
activity per scenario. 


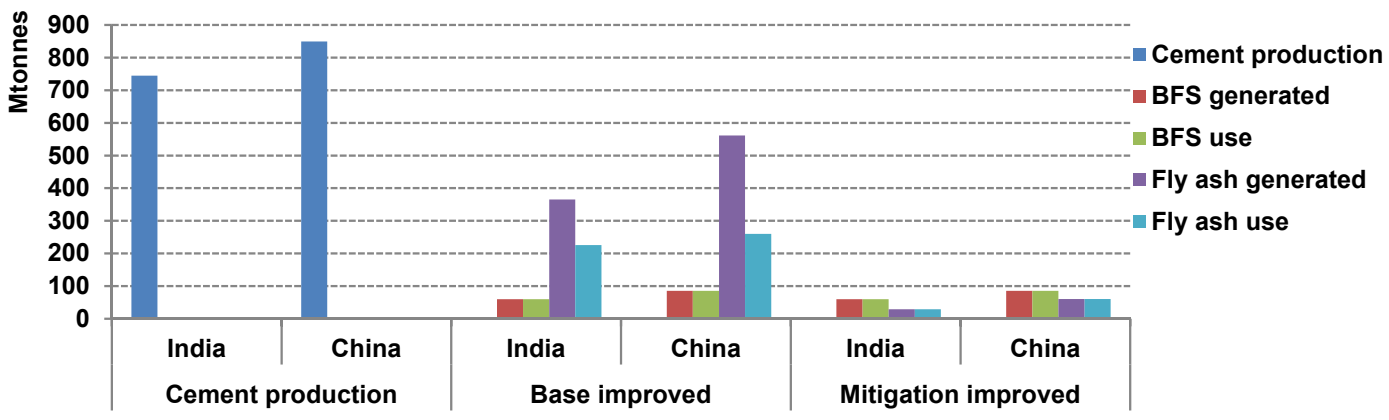

Fig. 4. SCM availability and utilization in India and China in the (a) baseline improved and (b) mitigation improved scenarios in 2050 .

policy measure.

In the baseline improved scenario, energy use is considerably lower than in the baseline original scenario. However, when taking into account the limited availability of SCMs the energy use is even higher. In the mitigation improved scenario the 2100 energy use is $14 \%$ higher when compared to the mitigation original scenario (see Fig. 3). In 2100 and in the baseline improved scenario, the $\mathrm{CO}_{2}$ emissions are $22 \%$ lower than in the baseline original scenario. Under both mitigation scenarios the $\mathrm{CO}_{2}$ emissions are similar as CCS is employed to reduce the $\mathrm{CO}_{2}$ emissions to a certain level. However, it should be noted that under the mitigation improved scenario the $\mathrm{CO}_{2}$ emissions that need to be captured are considerably higher as more clinker is produced which translates into more emissions.

Using the methodology developed in this analysis allows for a better understanding of the impact of SCM availability on the cement composition across the world. Fig. 4 shows the amounts of BFS and fly ash available in China and India but also the amounts of BFS and fly ash that can be utilized under the baseline improved and mitigation improved scenarios for 2050 . It can be seen that under the baseline improved scenario large quantities of fly ash are generated in both India and China however only a part is utilized by the cement industry due to the additive constraints. Under the mitigation improved scenario the low availability of fly ash limits the utilization in cement plants. Tables 15 and 16 in Appendix $C$ show the same results but for all 26 regions used in IMAGE in 2050 and 2100.

In this analysis, trade of SCMs is not included. When SCM availability is higher than the possible utilization, a part remains unexploited. For example, as seen in Fig. 4 in the China region, about 560 Mtonnes of fly ash will be generated but only 260 Mtonnes is used in cement production. Similar is the case in India, South Africa, Central Europe, Ukraine region, Kazakhstan region, Russian Federation, Korea region, Japan, and Oceania. In total, 1450 Mtonnes of fly ash are generated in 2050 of which 930 Mtonnes are used in blended cements. The majority of the remaining 520 Mtonnes fly ash is in China (58\%) and in India (27\%). If traded, it can be used by other regions to lower the clinker to cement ratio. In such a case 390 Mtonnes could be used by the other regions. To justify long shipments however the cement price should be high. At current cement prices fly ash can be economically transferred within a small radius from the power plants. Longer shipments via rail are economically feasible only if large quantities of fly ash are transported [37].

BFS is only available in lower quantities. In 2050, 293 Mtonnes of BFS become available globally and are all used in blended cements. As shown in Fig. 4, in the mitigation improved scenario, fly ash is no longer available in large quantities. In 2050, about 140 Mtonnes become available and are all utilized. The amount of BFS available remains the same.

Fig. 5 shows the cement composition under the two scenarios for 2050 in the major cement producing regions (cement composition for all 26 regions used in IMAGE for 2050 and 2100 can be seen in Figs. 9 and 10 in Appendix D). In the baseline improved scenario, the global average clinker to cement ratio is estimated at $62 \%$. In the mitigation improved scenario, the global average clinker to cement ratio is estimated at $73 \%$. The limited availability of fly ash is visible. Limestone in the mitigation improved scenario is used in greater quantities as less of the other SCMs are available. In this study limestone cement is limited to $15 \%$.

\section{Discussions and conclusion}

\subsection{Scope for adding bottom-up detail to long-term energy models}

This analysis has shown that both the inclusion of retrofitting with energy efficient technologies/measures and the modeling of the clinker content in cement that considers the availability of SCMs have an important impact on model results.

When retrofitting is taken into account, many measures/technologies are identified as cost-effective and consequently adopted, lowering the energy use for cement making for the relatively short term. Retrofitting can save 9.8 EJ of energy globally within the period 2010-2035 in a baseline scenario, while in a mitigation scenario $11 \mathrm{EJ}$ of energy can be saved ( 4 and $5 \%$ of overall $\mathrm{CO}_{2}$ emissions within this period).

When the availability of SCMs is taken into account, mainly BFS and fly ash, in a mitigation scenario, the potential for clinker to cement ratio reduction is significantly narrowed down. This is because in a mitigation scenario, many coal-fired power plants are considered to shut down resulting in a dramatic decrease in fly ash availability. In this analysis, in the mitigation improved scenario, clinker production will reach 3060 Mtonnes in 2050 and 3340 Mtonnes in 2100, 9\% and 14\% higher when compared to the mitigation original scenario resulting in higher energy consumption.

To improve the representation of the cement industry in energy models and better identify the energy and GHG savings that i) energy efficiency and ii) material efficiency (in this analysis restricted only to clinker substitution) can offer, it is important to take into account key industry characteristics. For energy efficiency it is important to consider the extent to which energy efficiency improvements have already been adopted in certain regions and identify the remaining energy efficiency potential that has not been captured so far. For material efficiency it is important to consider that mitigation policies in other areas of the model, in this case in the energy sector, can affect the GHG mitigation potential of material efficiency in the cement industry.

We have shown that it is possible to incorporate a relatively simple modeling approach for retrofitting and dynamic modeling of the clinker to cement ratio based on bottom-up available information in energy models. An alternative option would be to couple existing technically detailed bottom-up simulation models, e.g. the FORECAST model [38] 

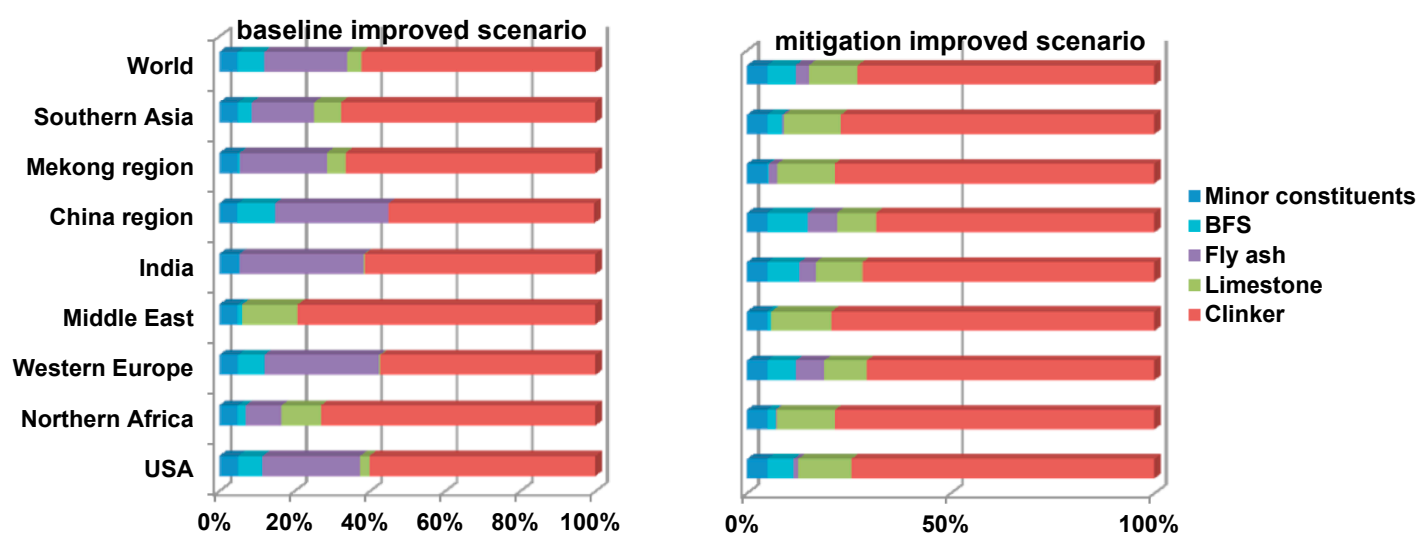

Fig. 5. Cement composition in 2050 under the (a) baseline improved and the (b) mitigation improved scenarios.

to IAMs. However, this can also be challenging as there are many differences in model structures [39], regional breakdown etc.

The developed modeling approach in this analysis still has certain limitations, mostly as result of the required simplifications:

Utilization rate of SCMs: In this analysis, the regional availability and certain restrictions on the level of technical SCM to cement ratio (depending on the SCM type) determine the level of utilization. However, more parameters such as product and national standards, price and trade of SCMs can impact the utilization rate. To model all these factors on a regional level for the near and distant future is complex and uncertain.

Trade of SCMs: If trade of SCMs was also included, the 520 Mtonnes of unexploited fly ash identified for 2050 under the baseline improved scenario, can be used by other regions. However, due to restrictions on the fly ash content of fly ash cement (fly ash content can be $35 \%$ ) only 390 Mtonnes can realistically be used by the other regions. The utilization of the left over fly ash would decrease the clinker to cement ratio from $62 \%$ to $57 \%$ as fly ash cement has higher content in SCMs than limestone cement.

Variety of SCMs: This study only took into account the use of BFS, fly ash and limestone as clinker replacements in cement. However, pozzolanas, either natural or artificial, could also be used to further reduce the clinker to cement ratio. Currently, the annual pozzolana production is limited (see Table 6) and data on the actual regional availability/ reserves of some natural pozzolanas, such as volcanic ash, is not available. Because of data limitations, the analysis was limited to these three materials.

Low-carbon cements: To further decrease the clinker content in the mitigation scenario low-carbon cements using alternative additives should be used. The popular geopolymer or alkaline-activated cements even if they overcome the technical barriers for use in structural applications they can only be produced in limited volumes. This is because to replace clinker, they also rely on the use of materials with either limited availability i.e., fly ash, BFS and pozzolanas, or expensive to produce such as metakaolin [28]. Other novel low-carbon cements with similar performances to Portland cement while less $\mathrm{CO}_{2}$ intensive are the calcium sulfoaluminate and magnesium cements [40]. Although promising as they use alternative additives they are currently under development and have not been assessed in this study. Until the wide application of such novel cements however, slags and fly ash, should be optimally generated, conserved (instead of being disposed) and used as additives in cement making offering thereby the highest climate change mitigation potential.

Quality of SCMs: A main assumption in this analysis is on the quality of the available BFS and fly ash. To estimate the lowest possible clinker to cement ratio it was considered that all BFS and fly ash generated are of sufficient quality for use as clinker replacements. This means that all BFS is granulated (the current granulation level is about 75\%) and that all fly ash available, is of sufficient quality for use in cements. Transforming however all generated fly ash to desired quality for use as SCM remains a challenge. If not all fly ash can be used, the clinker to cement ratio would be even higher under the 450 scenario.

Uncertainties: It is hard to determine the exact implementation rates for all energy efficiency technologies/measures shown in Section 3. To restrict the uncertainties on these figures we tried to base our estimates on reported information for the main measures offering the largest part of energy savings.

For each of the technologies/measures to be adopted a specific energy savings potential (GJ/tonne clinker) has been assigned (see Table 10 in Appendix A). This number is based on information concerning the U.S. industry. In reality, the energy saving potentials would be different for each region based on the average energy intensity for clinker production in that region. However, the difference is not expected to be large.

In this paper, we only analyzed energy efficient measures/technologies for clinker production with the dry process. The only option that was considered for energy efficient improvement in plants that operate wet, semi-wet or semi-dry kilns would be the switch to the dry process. In some cases, for example Russia, this switch was not identified as costeffective and was not implemented under the baseline improved scenario. If the option of energy efficiency improvement measures specific to the wet process was also considered, some of these measures could be cost-effective and thereby decrease the energy use in these regions.

Another uncertainty lies on the amount of fly ash generated from coal-fired power plants in the various regions. In reality, the volumes of fly ash generated will depend on the quality of coal and the burning process and both can vary through time. In this analysis, we have assumed a fixed fly ash generation that only varies per region.

\subsection{Conclusions}

The industrial sector is complex, primarily due to the heterogeneity of products manufactured, e.g. chemicals and petrochemicals, cement, glass, metals such as steel and aluminium, that are all produced in different industrial processes. Each sector has its specific characteristics and dynamics. To better understand the decarbonisation options under different climate policy scenarios for these high consumption industry sectors it is important to include the key industry sub-sector specific characteristics that affect its energy development. In this paper, we specifically focus on the cement sector, providing an overview of the 
state-of-the-art of cement sector modelling in IAMs, proposing ways for improvement, and testing these in the IAM IMAGE.

There is a limited representation of the cement industry in long-term energy models. Disaggregating the non-metallic minerals sector and modeling the physical demand instead of directly modeling the energy demand will allow the inclusion of bottom-up information on production technologies and regional energy efficiency and material efficiency potentials.

For the cement industry, important parameters that affect the energy development are the current regional energy and carbon dioxide intensities, adoption rates of energy efficiency technologies, energy efficiency and material intensity. Besides the guide for modelling the cement sector, presented in the appendix, in this paper, we propose two modeling approaches for cement for improvement of these processes in long-term energy models: (1) retrofitting with energy efficient technologies and (2) reducing the clinker to cement ratio. Based on this a number of key conclusions can be drawn.

There is a significant potential for energy savings from retrofitting. Cement plants that were built a number of years or even decades ago and that are still in operation are not as efficient as newly built cement plants. In addition, the level of energy efficiency and the production technologies used for cement production differ between regions. For the existing plants, retrofitting with energy efficient technologies/measures can offer significant energy savings, already in the short term, that cannot be neglected. Bottom-up details on the regional average energy intensity and on production technologies used along with information on energy efficiency options can be used by energy models to identify the potential for energy savings from retrofitting.

There is a significant potential for energy savings from increased clinker substitution. The effectiveness of implementing this strongly depends on the activity in other sectors and the scenario in question. Relating the clinker content in cement to the development of the steel industry and the electric power industry can have a significant impact on projecting energy use in the cement sector. For example, in a scenario where less coal-fired power plants are built or steel demand weakens, the availability on supplementary cementitious materials will decrease the potential for greenhouse gas abatement in the cement industry through clinker substitution. These results confirm the crucial role of connections between industries and show that emission abatement measures in one industry can indirectly impact another. In such a case, to achieve even higher clinker substitution rates.

In addition, these results highlight that the production/generation of high and consistent quality supplementary cementitious materials and their effective utilization in processes such as cement making where they have the potential to significantly lower greenhouse gas emissions is of crucial importance especially in times/scenarios of low availability of these materials.

Both measures can offer significant energy savings in the short term. Both retrofitting and the reduction of the clinker to cement ratio can offer significant energy and greenhouse gas savings already in the short term. These are not highly innovative measures surrounded by high uncertainties but well known measures with tangible energy and greenhouse gas emission savings potentials.

\section{Acknowledgement}

The research leading to these results has received funding from the European Union Seventh Framework Programme FP7/2007-2013 under grant agreement no. 308329 (ADVANCE).

Appendix A. Energy efficiency measures/technologies for clinker production

See Tables 10 and 11.

Table 10

Energy efficiency measures for clinker making - dry process cement plants [19].

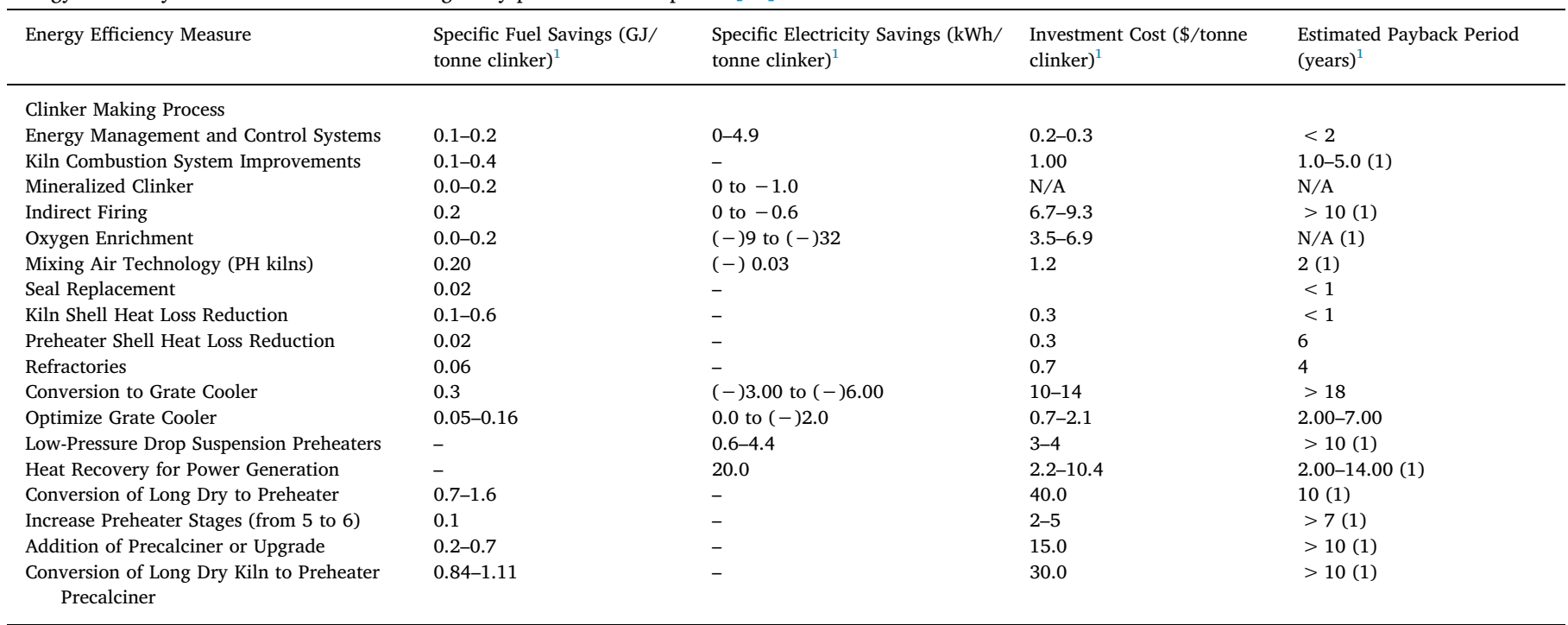

1 The estimated energy and expenditure savings and payback periods are averages for indication, based on the average performance of the U.S. cement industry (e.g. clinker to cement ratio). The actual savings and payback period may vary by project based on the specific conditions in the individual plant. 
Table 11

Estimated implementation rates of the different energy efficiency technologies in year 2010.

\begin{tabular}{|c|c|c|c|c|c|c|c|c|c|c|c|}
\hline $\begin{array}{l}\text { Energy Efficiency Measures for } \\
\text { Clinker Production }\end{array}$ & Europe & Africa & $\begin{array}{l}\text { Asia \& Oceania (excl. } \\
\text { China, India and CIS) }\end{array}$ & Brazil & $\begin{array}{l}\text { Central } \\
\text { America }\end{array}$ & China & CIS & Middle East & $\begin{array}{l}\text { North } \\
\text { America }\end{array}$ & $\begin{array}{l}\text { South America } \\
\text { (excl. Brazil) }\end{array}$ & India \\
\hline $\begin{array}{l}\text { Energy Management and Control } \\
\quad \text { Systems }\end{array}$ & $20 \%$ & $50 \%$ & $25 \%$ & $30 \%$ & $20 \%$ & $20 \%$ & $10 \%$ & $20 \%$ & $20 \%$ & $30 \%$ & $15 \%$ \\
\hline $\begin{array}{l}\text { Kiln Combustion System } \\
\text { Improvements }\end{array}$ & $5 \%$ & $50 \%$ & $10 \%$ & $40 \%$ & $30 \%$ & $20 \%$ & $10 \%$ & $20 \%$ & $30 \%$ & $35 \%$ & $15 \%$ \\
\hline Mineralized Clinker & $5 \%$ & $10 \%$ & $10 \%$ & $10 \%$ & $10 \%$ & $5 \%$ & $5 \%$ & $10 \%$ & $10 \%$ & $10 \%$ & $2 \%$ \\
\hline Indirect Firing & $5 \%$ & $10 \%$ & $10 \%$ & $10 \%$ & $10 \%$ & $5 \%$ & $5 \%$ & $10 \%$ & $10 \%$ & $10 \%$ & $2 \%$ \\
\hline Oxygen Enrichment & $5 \%$ & $10 \%$ & $10 \%$ & $10 \%$ & $10 \%$ & $5 \%$ & $5 \%$ & $10 \%$ & $10 \%$ & $10 \%$ & $2 \%$ \\
\hline Mixing Air Technology (PH kilns) & $5 \%$ & $10 \%$ & $10 \%$ & $10 \%$ & $10 \%$ & $5 \%$ & $5 \%$ & $10 \%$ & $10 \%$ & $10 \%$ & $2 \%$ \\
\hline Seal Replacement & $25 \%$ & $30 \%$ & $25 \%$ & $30 \%$ & $25 \%$ & $25 \%$ & $10 \%$ & $25 \%$ & $25 \%$ & $25 \%$ & $10 \%$ \\
\hline Kiln Shell Heat Loss Reduction & $5 \%$ & $40 \%$ & $20 \%$ & $40 \%$ & $35 \%$ & $20 \%$ & $10 \%$ & $25 \%$ & $30 \%$ & $40 \%$ & $5 \%$ \\
\hline Preheater Shell Heat Loss Reduction & $5 \%$ & $40 \%$ & $35 \%$ & $40 \%$ & $35 \%$ & $35 \%$ & $10 \%$ & $25 \%$ & $35 \%$ & $35 \%$ & $10 \%$ \\
\hline Refractories & $0 \%$ & $0 \%$ & $0 \%$ & $0 \%$ & $0 \%$ & $0 \%$ & $0 \%$ & $0 \%$ & $0 \%$ & $0 \%$ & $0 \%$ \\
\hline Conversion to Grate Cooler & $20 \%$ & $30 \%$ & $20 \%$ & $30 \%$ & $20 \%$ & $20 \%$ & $20 \%$ & $20 \%$ & $20 \%$ & $20 \%$ & $12 \%$ \\
\hline Upgrade clinker cooler & $20 \%$ & $20 \%$ & $20 \%$ & $20 \%$ & $20 \%$ & $20 \%$ & $20 \%$ & $20 \%$ & $20 \%$ & $20 \%$ & $12 \%$ \\
\hline Optimize Grate Cooler & $30 \%$ & $70 \%$ & $80 \%$ & $70 \%$ & $80 \%$ & $35 \%$ & $80 \%$ & $80 \%$ & $80 \%$ & $80 \%$ & $12 \%$ \\
\hline $\begin{array}{l}\text { Low-Pressure Drop Suspension } \\
\quad \text { Preheaters }\end{array}$ & $25 \%$ & $25 \%$ & $25 \%$ & $25 \%$ & $25 \%$ & $25 \%$ & $25 \%$ & $25 \%$ & $25 \%$ & $25 \%$ & $25 \%$ \\
\hline Heat Recovery for Power Generation & $25 \%$ & $25 \%$ & $25 \%$ & $25 \%$ & $25 \%$ & $25 \%$ & $25 \%$ & $25 \%$ & $25 \%$ & $25 \%$ & $25 \%$ \\
\hline Conversion of Long Dry to Preheater & $0 \%$ & $0 \%$ & $0 \%$ & $0 \%$ & $0 \%$ & $0 \%$ & $0 \%$ & $0 \%$ & $0 \%$ & $0 \%$ & $0 \%$ \\
\hline $\begin{array}{l}\text { Increase Preheater Stages (from } 5 \text { to } \\
\text { 6) }\end{array}$ & $10 \%$ & $30 \%$ & $20 \%$ & $30 \%$ & $20 \%$ & $20 \%$ & $20 \%$ & $20 \%$ & $20 \%$ & $20 \%$ & $10 \%$ \\
\hline Addition of Precalciner or Upgrade & $29 \%$ & $11 \%$ & $9 \%$ & $0 \%$ & $31 \%$ & $0 \%$ & $4 \%$ & $12 \%$ & $18 \%$ & $33 \%$ & $0 \%$ \\
\hline $\begin{array}{l}\text { Conversion of Long Dry Kiln to } \\
\text { Preheater Precalciner }\end{array}$ & $10 \%$ & $2 \%$ & $0 \%$ & $0 \%$ & $0 \%$ & $0 \%$ & $4 \%$ & $0 \%$ & $12 \%$ & $0 \%$ & $0 \%$ \\
\hline $\begin{array}{l}\text { Conversion from Wet to Dry } \\
\text { precalciner Kiln }\end{array}$ & $6 \%$ & $4 \%$ & $0 \%$ & $0 \%$ & $0 \%$ & $10 \%$ & $58 \%$ & $0 \%$ & $9 \%$ & $0 \%$ & $0 \%$ \\
\hline $\begin{array}{l}\text { Conversion from Semi-Wet Semi to Dry } \\
\text { precalciner Kiln }\end{array}$ & $8 \%$ & $0 \%$ & $0 \%$ & $0 \%$ & $0 \%$ & $0 \%$ & $3 \%$ & $0 \%$ & $0 \%$ & $0 \%$ & $0 \%$ \\
\hline
\end{tabular}

\section{Appendix B. Basic guidelines for modeling the cement industry}

\section{B.1. Energy demand}

There are three main energy consuming processes in cement manufacturing: raw material preparation, clinker production (limestone calcination) and cement grinding. Energy is consumed throughout cement manufacture and can be broken down into: (i) electricity use for raw material preparation; (ii) fuel and electricity use in clinker calcination; (iii) electricity use for clinker grinding; and (iv) fuel use for drying raw materials and additives (e.g. slag powder) (see Eq. (1A)). Table 12 shows all variable definitions used in the equations. The most energy intensive step is the calcination of clinker, responsible for the majority of fuel use [19].

$E_{\text {total }, t}=E_{\text {rawmaterialpre. }, t}+E_{\text {fuel, }, \text { kiln }, t}+E_{\text {el. }, \text { kiln }, t}+E_{\text {cementgrinding, },}+E_{\text {additivesdrying, } t}$

Table 12

Variable definitions.

\begin{tabular}{|c|c|c|}
\hline Variable & Definition & Unit \\
\hline$I$ & $\mathrm{i}=1,2$ refers to the type of kilns used: 1 ) dry and 2) wet & None \\
\hline$J$ & $\mathrm{j}$ refers to the different types of fuels used & None \\
\hline Kiln $_{\text {ratio,i,t }}$ & The share of clinker produced with kiln type $\mathrm{i}$ in year $\mathrm{t}$ & $\%$ \\
\hline$S E C_{\text {thermal, }, \text { t }}$ & Thermal energy use of kiln type $i$ in year $t$ & GJ/tonne clinker \\
\hline$S E C_{\text {elec, }, i, t}$ & $\begin{array}{l}\text { Electricity use of kiln type i in year t. It includes the electricity use for fuel preparation, and the electricity for operating the kiln, fans and } \\
\text { coolers }\end{array}$ & GJ/tonne clinker \\
\hline$S E C_{\text {total el.,t }}$ & Electricity use for cement making in year $t$ & GJ/tonne cement \\
\hline$E_{\text {total, } t}$ & Total energy use in cement manufacture in year $t$ & PJ \\
\hline$E_{\text {cement grinding,t }}$ & Total electricity use for cement grinding in year $\mathrm{t}$ & PJ \\
\hline$E_{\text {raw material prep. } t}$ & Total electricity use for raw material preparation in year $t$ & PJ \\
\hline$E_{\text {additives drying,t }}$ & Total energy use for additives drying in year $\mathrm{t}$ & PJ \\
\hline$E_{\text {fuel }, \text { kiln }, t}$ & Total fuel use in cement kilns in year $t$ & PJ \\
\hline$E_{e l, k i l n, t}$ & Total electricity use in cement kilns in year $\mathrm{t}$ & PJ \\
\hline$Q_{\text {cement }, t}$ & Total cement output in year $t$ & Mtonnes cement \\
\hline$Q_{\text {clinker,t }}$ & Total clinker output in year $\mathrm{t}$ & Mtonnes clinker \\
\hline $\mathrm{CO}_{2, \text { total }, t}$ & Total $\mathrm{CO}_{2}$ emissions from cement production in year $\mathrm{t}$ & Mtonnes $\mathrm{CO}_{2}$ \\
\hline $\mathrm{CO}_{2-\text { fuel, }}$ & Total $\mathrm{CO}_{2}$ emissions from fuel combustion in year $\mathrm{t}$ & Mtonnes $\mathrm{CO}_{2}$ \\
\hline $\mathrm{CO}_{2 \text {-process, } t}$ & Total $\mathrm{CO}_{2}$ emissions inherited to the clinker calcination process in year $\mathrm{t}$ & Mtonnes $\mathrm{CO}_{2}$ \\
\hline $\mathrm{CO}_{2-e l, t}$ & Total $\mathrm{CO}_{2}$ emissions from electricity generation in year $\mathrm{t}$ & Mtonnes $\mathrm{CO}_{2}$ \\
\hline Fuel $_{\text {ratio, }, t, t}$ & Fuel share of fuel $\mathrm{j}$ in year $\mathrm{t}$ & $\%$ \\
\hline$C E F_{f u e l, j}$ & $\mathrm{CO}_{2}$ emission factor of fuel $\mathrm{j}$ & $\mathrm{kgCO}_{2} / \mathrm{GJ}$ \\
\hline$S E C_{\text {thermal, } t}$ & Thermal energy use for clinker calcination in year $t$ & $\mathrm{MJ} /$ tonne \\
\hline$C E F_{e l, t}$ & $\mathrm{CO}_{2}$ emission factor for electricity generation in year $\mathrm{t}$ & $\mathrm{kgCO}_{2} / \mathrm{GJ}$ \\
\hline Clinker $_{\text {ratio,t }}$ & The clinker to cement ratio in year $\mathrm{t}$ & $\%$ \\
\hline
\end{tabular}


Due to the limited regional information, not all variables in Eq. (1A) can be defined/determined for every world region. In the following paragraphs we show how the total energy use $\left(E_{\text {total, },}\right)$, fuel $\left(S E C_{\text {thermal, }, t}\right)$ and electricity $\left(S E C_{\text {total el, }, t}\right)$ can be calculated on a regional basis based on available information. Since information on regional electricity use per process step (i.e. raw material preparation, clinker burning and cement and additive grinding) is not available, we show an approachto determine the total electricity use in cement plants.

\section{B.2. Fuel use}

Most of the energy consumed in a cement plant is in the form of fuel that is used to fire the kiln. A mixture of mainly limestone, silicon oxides, aluminium oxides and iron oxides are burned in a kiln to produce clinker. Based on the moisture content of the raw materials, clinker production can take place in a wet, dry, semi-dry or semi-wet kiln. The dry process is the most energy efficient as the evaporation needs are low. The Commonwealth of Independent States (CIS) has a high share of the wet process (85\%), while other regions that employ this technology are Europe (6\%), China (10\%) and the North America (9\%) (see Table 3). Countries with a high share of the wet process will have a higher average fuel use in clinker making. Table 13 shows the typical energy intensities of the different kiln technologies.

Below we show two simple approaches that could be used by energy models for the construction of their base year energy use: (1) by using regional information readily available on the level of energy use per tonne of clinker or (2) by taking into account information on the production technology used in each region and the typical energy intensities of each technology.

Table 13

Fuel use by type of kiln technology.

\begin{tabular}{|c|c|c|c|}
\hline Kiln technology & JRC-IPTS [27] (GJ/tonne clinker) & U.S. EPA [72] (GJ/tonne clinker) & Weighted average (GJ/tonne clinker) [73] \\
\hline Dry with preheater and precalciner & $3.0-4.0$ & $2.9-3.8$ & 3.3 \\
\hline Dry with preheater (without precalciner) ${ }^{1}$ & $3.1-4.2$ & 4.4 & 3.7 \\
\hline Long dry (without preheater and precalciner) & up to 5.0 & 5.2 & 4.5 \\
\hline Semi-wet, semi-dry & $3.3-5.4^{2}$ & - & 3.8 \\
\hline Wet & $5.0-6.4$ & 5.7-10.2 (6.0 typical) & 6.3 \\
\hline
\end{tabular}

1 The energy use differs with the number of preheater stages: 3.4-3.8 GJ/tonne for 3 preheater stages; 3.2-3.6 GJ/tonne for 4 preheater stages; 3.1-3.5 GJ/tonne for 5 preheater stages; 3.0-3.4 GJ/tonne for 6 preheater stages [28].

2 The energy use for raw material drying is not included.

\section{Approach 1}

The thermal energy use for clinker production ranges between 3.1 and 5.0 GJ/tonne clinker between the major world regions (see Fig. 1). It differs mainly due to the kiln technology type used and the level of energy efficiency. The lowest energy consumption is observed in India where cement capacity increased significantly in recent years. The highest is in CIS which still relies heavily on the wet process.

\section{Approach 2}

The fuel requirements for clinker making could also be estimated based on the information available on the type of technologies used (e.g. wet, dry, semi-dry) in the different regions (see Table 3), the typical energy intensities of these technologies (Table 13), and the amount of clinker produced in each region (see Eq. (2A)). Statistics on clinker production are not available. However, clinker production can be estimated by multiplying the reported cement production with the clinker to cement ratio of that region (see Fig. 6). Clinker can be substituted by industrial byproducts such as coal fly ash, blast furnace slag or pozzolanic materials (e.g. volcanic material). The relative importance of additive use can be expressed by the clinker to cement ratio.

$E_{\text {fuel }, k i l n, t}=\left(\sum_{i}\right.$ Kiln $\left._{\text {ratio }, i, t} \times S E C_{\text {thermal }, i, t}\right) \times Q_{\text {clinker }, t}$

Approach 2 leads to slightly different results from the fuel use appearing in Approach 1. For most of the regions, Europe, Africa, Central America, CIS, Middle East, Asia \& Oceania, North America and South America when using approach 2 and the average energy intensity of the technologies

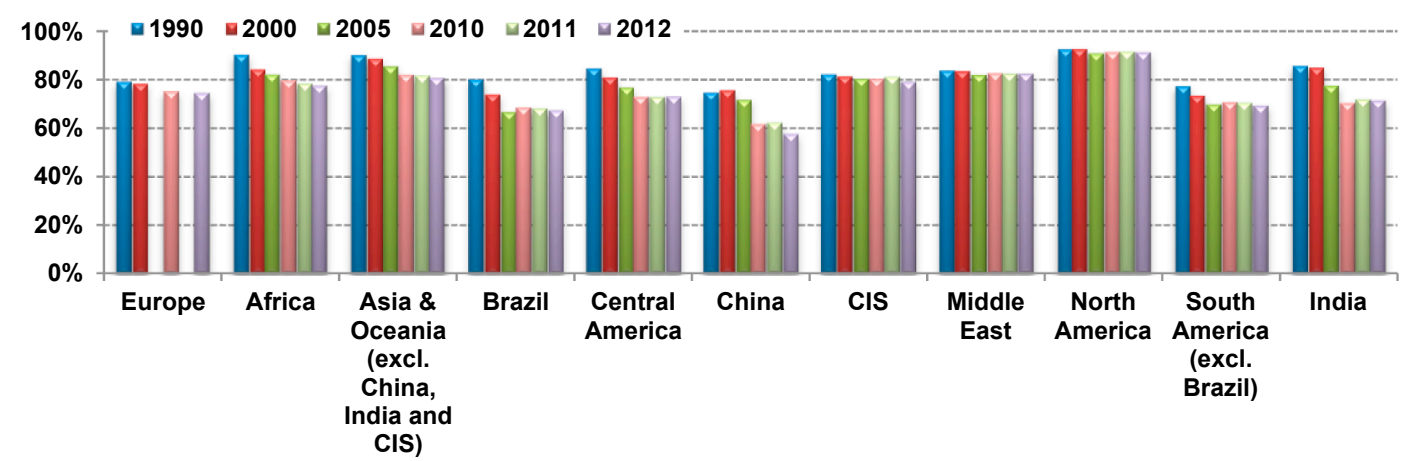

Fig. 6. Clinker to cement ratios per region [43-45]. 
shown in Table 13, the estimated fuel use is close ( $\pm 0.15 \mathrm{GJ} /$ tonne clinker) to the fuel use shown in approach 1 . For China, India, and Brazil, the result in approach 2 is a higher fuel use (0.4-0.5 GJ/tonne) than approach 1 . New efficient capacities built in these regions have decreased the overall energy use and this could be corrected in approach 2 by using lower typical energy intensities than the ones appearing in Table 13.

Total electricity use (electricity use for raw material preparation, kiln operation, cement and additives grinding) accounts for about $20 \%$ of the overall energy needs in a cement plant and ranges between 90 and $150 \mathrm{kWh} /$ tonne cement [27]. Electricity is primarily used for raw material, fuel and cement grinding. The typical power consumption breakdown in a cement plant using the dry process is as follows [28]:

- 5\% raw material extraction and blending,

$-24 \%$ raw material grinding,

- $6 \%$ raw material homogenization,

$-22 \%$ clinker production and fuel grinding,

$-38 \%$ cement grinding, and

$-5 \%$ conveying, packaging and loading.

Energy models could develop their base year energy use based on the information that is available on the regional total electricity use per tonne of cement (approach 1) or based on the type of technologies used and the typical energy intensities (approach 2). The lack of information on the regional installed capacity of grinding technologies will limit the usability of approach 2 by the models. However, the approach is presented below as models could use the information to determine regional electricity use for clinker burning only. In addition, we present the typical electricity intensities of the different grinding technologies.

\section{Approach 1}

According to the WBSCD database, in 2012, the total electricity use ranged between 81 and $126 \mathrm{kWh} /$ tonne cement. The lowest electricity use is observed in India and the highest in the North America and CIS (see Fig. 7).

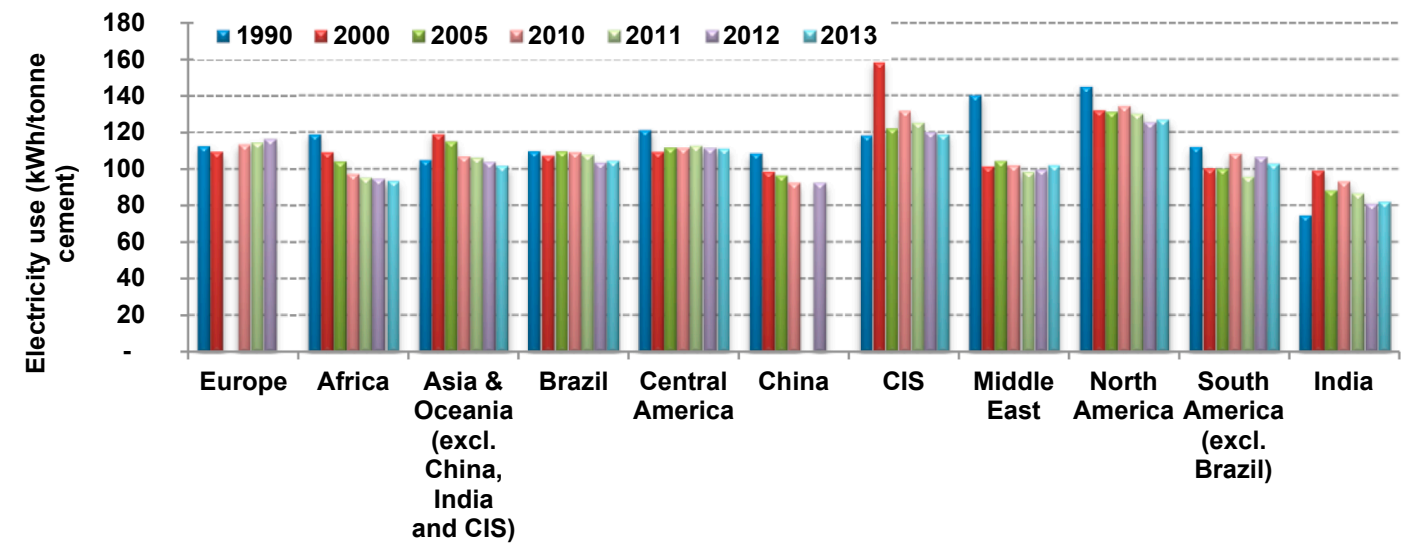

Fig. 7. Average electricity consumption for cement making per region [43,44].

\section{Approach 2}

The electricity use in kilns can be estimated based on the typical energy intensities of the different kiln types and their production share in each region (see Table 3). About $22 \%$ of the electricity consumed is used for clinker making and fuel grinding. Plants using the wet process consume about $32 \mathrm{kWh}$ /tonne clinker for fuel preparation and for operating the kiln, fans and the coolers while plants operating the dry process consume about 36 $\mathrm{kWh} /$ tonne clinker [19]. The electricity use for clinker making in a specific region can be estimated from Eq. (3A).

$E_{\text {el }, k i l n, t}=\left(\sum_{i} K_{i l n_{\text {ratio }, i, t}} \times S E C_{\text {elec }, i, t}\right) \times Q_{\text {clinker }, t}$

More than $60 \%$ of the electricity consumed is used for grinding. Electricity use is influenced by the grinding technology employed, material

Table 14

Electricity use for raw material and cement grinding [19].

\begin{tabular}{llll}
\hline Grinding technology & Raw material grinding $(\mathrm{kWh} / \text { tonne raw material })^{1}$ & ${\text { Cement grinding }(\mathrm{kWh} / \text { tonne cement })^{1}}$ & ${\text { Fuel grinding }(\mathrm{kWh} / \text { tonne coal })^{1}}^{1}$ \\
\hline Ball mill & $19-29$ & $32-37$ & \\
Horizontal roller mill & $7-8$ & $18-21$ & $15-23$ \\
Vertical roller mill & $<10$ & $21-23$ & $50-66$ \\
Roller presses & 15 & $19-21$ & $28-29$ \\
Impact mill & & & \\
Tube mill & & & \\
\hline
\end{tabular}

${ }^{1}$ The actual electricity use will heavily depend on the material properties and required fineness. 
properties and product fineness. Plants employing high pressure roller presses and roller mills are less electricity intensive than plants using ball mills. Currently, about $70 \%$ of installed mills in grinding plants are ball mills. In newer plants this share is lower, estimated at $50 \%$ as more energy efficient mills types are used [41].

Although there is information available on the typical energy intensities of the various grinding technologies (see Table 14), information on the share of the different grinding technologies per world region is scarce. Therefore it is not possible to estimate the regional electricity use, based on this data alone. Approach 2 can only be used to estimate electricity use for clinker making.

\section{B.3. Total energy use}

The total energy consumption of cement making in different world regions can be estimated by Eq. (4A). As the available data on the electricity use involve the total electricity use, in the equation below, $\mathrm{E}_{\text {raw material prep.,t, }} \mathrm{E}_{\text {el.,kiln,t }}$, and $\mathrm{E}_{\text {cement grinding,t }}$ from Eq. (1A) are aggregated into SEC el.,t•

$E_{\text {total }, t}=\left(\sum_{i}\right.$ Kiln $\left._{\text {ratio }, i, t} \times S E C_{\text {thermal }, i, t}\right) \times Q_{\text {clinker }, t}+S E C_{\text {totalel }, t} \times Q_{\text {cement }, t}$

A simple way to project energy use under a baseline scenario would be to assume that energy efficiency in cement manufacture improves annually by a certain rate. This improvement could be the result of an autonomous energy efficiency improvement and a policy induced energy efficiency improvement. The historical energy use trends for the cement industry indicate that in the past years, fuel use in clinker production and electricity use for cement production (total electricity use) experienced an annual decrease of $0.9 \%$ and $0.5 \%$, respectively [42].

\section{B.4. $\mathrm{CO}_{2}$ emissions}

Most of the $\mathrm{CO}_{2}$ emissions in cement making are released during clinker calcination. Approximately $62 \%$ of the $\mathrm{CO}_{2}$ emissions are process related while the remaining $38 \%$ is released during fuel combustion [27]. The $\mathrm{CO}_{2}$ emissions inherent to the process amount to $0.5262 \mathrm{~kg}$ per $\mathrm{kg}$ of clinker produced [27]. The $\mathrm{CO}_{2}$ emissions from fuel combustion depend on the energy intensity of the kiln system and the carbon intensity of the fuel used. To calculate the total amount of $\mathrm{CO}_{2}$ released in the atmosphere, the $\mathrm{CO}_{2}$ emissions from electricity generation also need to be added.

$$
\begin{aligned}
\mathrm{CO}_{2, \text { total }, t}= & \mathrm{CO}_{2-\text { fuel }, t}+\mathrm{CO}_{2-\text { process }, t}+\mathrm{CO}_{2-e l, t}=\sum_{j}\left(\text { Fuel }_{\text {ratio }, j, t} \times C E F_{\text {fuel }, j} \times S E C_{\text {thermal }, t}\right) \times Q_{\text {clinker }, t}+\sum_{i}\left(C E F_{\text {el. }, t} \times S E C_{\text {el. }, t}\right) \times Q_{\text {cement }, t} \\
& +0.5262 \times \text { Clinker ratio }, t \times Q_{\text {cement }, t}
\end{aligned}
$$

Fig. 8 shows the different types of fuels used in the cement industry. In Europe, around $45 \%$ is comprised by alternative fuels such as a variety of wastes such as tires, waste oil, plastics and solvents and biomass.

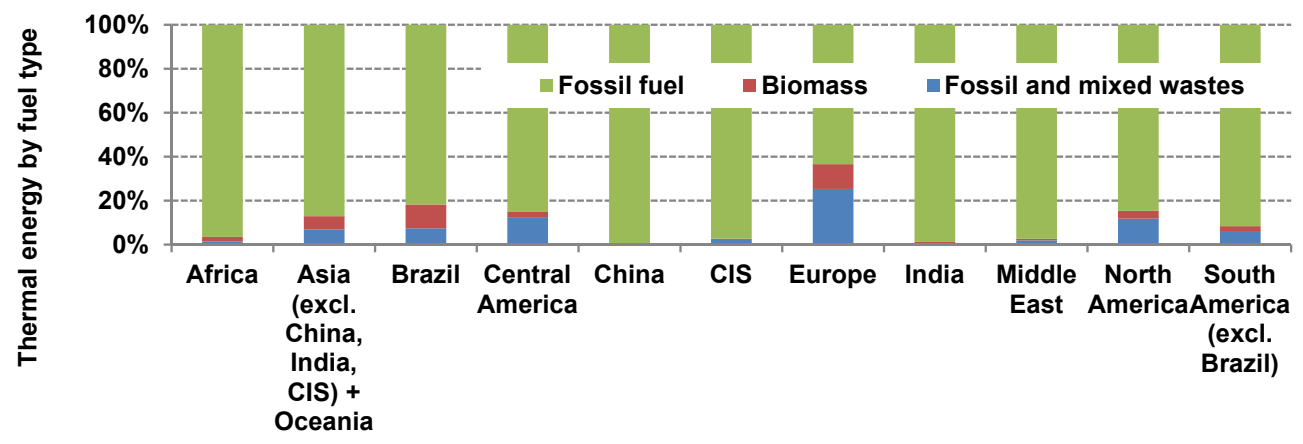

Fig. 8. Thermal energy use for clinker making by fuel type [43].

Appendix C. SCM availability and utilization in 2050 and 2100

See Tables 15 and 16.

Table 15

\begin{tabular}{|c|c|c|c|c|c|c|c|c|c|c|}
\hline \multirow[t]{2}{*}{ Regions } & \multicolumn{5}{|l|}{2050} & \multicolumn{5}{|l|}{2100} \\
\hline & $\begin{array}{l}\text { cement } \\
\text { production }\end{array}$ & BFS generated & BFS utilized $^{1}$ & $\begin{array}{l}\text { Fly ash } \\
\text { generated }\end{array}$ & $\begin{array}{l}\text { Fly ash } \\
\text { utilized }^{1}\end{array}$ & $\begin{array}{l}\text { cement } \\
\text { production }\end{array}$ & BFS generated & BFS utilized $^{1}$ & $\begin{array}{l}\text { Fly ash } \\
\text { generated }\end{array}$ & $\begin{array}{l}\text { Fly ash } \\
\text { utilized }^{1}\end{array}$ \\
\hline Canada & 28 & 2 & 2 & 3 & 3 & 34 & 1 & 1 & 4 & 4 \\
\hline USA & 171 & 11 & 11 & 44 & 44 & 215 & 7 & 7 & 67 & 67 \\
\hline Mexico & 69 & 2 & 2 & 18 & 18 & 74 & 1 & 1 & 42 & 25 \\
\hline $\begin{array}{r}\text { Rest Central } \\
\text { America }\end{array}$ & 45 & - & - & 10 & 10 & 49 & - & - & 47 & 17 \\
\hline Brazil & 99 & 14 & 14 & 9 & 9 & 89 & 9 & 9 & 55 & 26 \\
\hline
\end{tabular}

SCM availability and utilization in the baseline improved scenario in 2050 and 2100. 
Table 15 (continued)

\begin{tabular}{|c|c|c|c|c|c|c|c|c|c|c|}
\hline \multirow[t]{2}{*}{ Regions } & \multicolumn{5}{|l|}{2050} & \multicolumn{5}{|l|}{2100} \\
\hline & $\begin{array}{l}\text { cement } \\
\text { production }\end{array}$ & BFS generated & BFS utilized $^{1}$ & $\begin{array}{l}\text { Fly ash } \\
\text { generated }\end{array}$ & $\begin{array}{l}\text { Fly ash } \\
\text { utilized }^{1}\end{array}$ & $\begin{array}{l}\text { cement } \\
\text { production }\end{array}$ & BFS generated & BFS utilized $^{1}$ & $\begin{array}{l}\text { Fly ash } \\
\text { generated }\end{array}$ & $\begin{array}{l}\text { Fly ash } \\
\text { utilized }^{1}\end{array}$ \\
\hline $\begin{array}{l}\text { Rest South } \\
\text { America }\end{array}$ & 110 & 3 & 3 & 16 & 16 & 115 & 3 & 3 & 63 & 39 \\
\hline Northern Africa & 108 & 2 & 2 & 10 & 10 & 105 & 3 & 3 & 46 & 35 \\
\hline Western Africa & 225 & - & - & 11 & 11 & 507 & - & - & 277 & 177 \\
\hline Eastern Africa & 129 & 4 & 4 & 4 & 4 & 278 & 32 & 32 & 101 & 80 \\
\hline South Africa & 28 & 3 & 3 & 24 & 8 & 30 & 3 & 3 & 25 & 9 \\
\hline Western Europe & 253 & 18 & 18 & 77 & 77 & 266 & 10 & 10 & 160 & 88 \\
\hline Central Europe & 58 & 5 & 5 & 23 & 18 & 49 & 3 & 3 & 32 & 16 \\
\hline Turkey & 102 & 8 & 8 & 12 & 12 & 108 & 5 & 5 & 24 & 24 \\
\hline Ukraine region & 19 & 12 & 12 & 18 & 0 & 17 & 9 & 9 & 18 & 1 \\
\hline Kazachstan region & 34 & 4 & 4 & 12 & 10 & 33 & 3 & 3 & 27 & 10 \\
\hline Russian Federation & 71 & 16 & 16 & 38 & 16 & 67 & 12 & 12 & 47 & 17 \\
\hline Middle East & 199 & 2 & 2 & 0 & 0 & 215 & 3 & 3 & 111 & 74 \\
\hline India & 745 & 60 & 60 & 365 & 226 & 788 & 52 & 52 & 798 & 249 \\
\hline Korea region & 60 & 8 & 8 & 22 & 17 & 46 & 2 & 2 & 14 & 14 \\
\hline China region & 850 & 86 & 86 & 561 & 260 & 403 & 18 & 18 & 283 & 133 \\
\hline Mekong region & 263 & 1 & 1 & 61 & 61 & 276 & 1 & 1 & 138 & 96 \\
\hline Indonesia region & 127 & - & - & 22 & 22 & 118 & - & - & 54 & 42 \\
\hline Japan & 87 & 20 & 20 & 25 & 20 & 77 & 12 & 12 & 30 & 20 \\
\hline Oceania & 17 & 1 & 1 & 9 & 6 & 22 & 0 & 0 & 11 & 7 \\
\hline Southern Asia & 253 & 9 & 9 & 42 & 42 & 363 & 27 & 27 & 205 & 112 \\
\hline $\begin{array}{l}\text { Rest Southern } \\
\text { Africa }\end{array}$ & 76 & 3 & 3 & 13 & 13 & 151 & 16 & 16 & 114 & 44 \\
\hline World & 4223 & 293 & 293 & 1451 & 933 & 4493 & 231 & 231 & 2792 & 1426 \\
\hline
\end{tabular}

1 In this analysis only restrictions in utilization of these materials are availability and maximum additive content. It is assumed that the generated materials are of sufficient quality for use in blended cements.

Table 16

SCM availability and utilization in the mitigation improved scenario in 2050 and 2100 .

\begin{tabular}{|c|c|c|c|c|c|c|c|c|c|c|}
\hline \multirow[t]{2}{*}{ Regions } & \multicolumn{5}{|l|}{2050} & \multicolumn{5}{|l|}{2100} \\
\hline & $\begin{array}{l}\text { cement } \\
\text { production }\end{array}$ & BFS generated & BFS utilized $^{1}$ & $\begin{array}{l}\text { Fly ash } \\
\text { generated }\end{array}$ & $\begin{array}{l}\text { Fly ash } \\
\text { utilized }^{1}\end{array}$ & $\begin{array}{l}\text { cement } \\
\text { production }\end{array}$ & BFS generated & BFS utilized $^{1}$ & $\begin{array}{l}\text { Fly ash } \\
\text { generated }\end{array}$ & $\begin{array}{l}\text { Fly ash } \\
\text { utilized }^{1}\end{array}$ \\
\hline Canada & 28 & 2 & 2 & 0 & 0 & 34 & 1 & 1 & 0 & 0 \\
\hline USA & 171 & 11 & 11 & 2 & 2 & 215 & 7 & 7 & 20 & 20 \\
\hline Mexico & 69 & 2 & 2 & 1 & 1 & 74 & 1 & 1 & 7 & 7 \\
\hline $\begin{array}{r}\text { Rest Central } \\
\text { America }\end{array}$ & 45 & - & - & 0 & 0 & 49 & - & - & 5 & 5 \\
\hline Brazil & 99 & 14 & 14 & 0 & 0 & 89 & 9 & 9 & 6 & 6 \\
\hline $\begin{array}{l}\text { Rest South } \\
\text { America }\end{array}$ & 110 & 3 & 3 & 0 & 0 & 115 & 3 & 3 & 1 & 1 \\
\hline Northern Africa & 108 & 2 & 2 & 0 & 0 & 105 & 3 & 3 & 6 & 6 \\
\hline Western Africa & 225 & - & - & 0 & 0 & 507 & - & - & 9 & 9 \\
\hline Eastern Africa & 129 & 4 & 4 & 0 & 0 & 278 & 32 & 32 & 1 & 1 \\
\hline South Africa & 28 & 3 & 3 & 1 & 1 & 30 & 3 & 3 & 3 & 3 \\
\hline Western Europe & 253 & 18 & 18 & 17 & 17 & 266 & 10 & 10 & 23 & 23 \\
\hline Central Europe & 58 & 5 & 5 & 2 & 2 & 49 & 3 & 3 & 0 & 0 \\
\hline Turkey & 102 & 8 & 8 & 0 & 0 & 108 & 5 & 5 & 0 & 0 \\
\hline Ukraine region & 19 & 12 & 12 & 2 & 0 & 17 & 9 & 9 & 0 & 0 \\
\hline Kazachstan region & 34 & 4 & 4 & 5 & 5 & 33 & 3 & 3 & 8 & 8 \\
\hline Russian Federation & 71 & 16 & 16 & 2 & 2 & 67 & 12 & 12 & 2 & 2 \\
\hline Middle East & 199 & 2 & 2 & 0 & 0 & 215 & 3 & 3 & 3 & 3 \\
\hline India & 745 & 60 & 60 & 29 & 29 & 788 & 52 & 52 & 12 & 12 \\
\hline Korea region & 60 & 8 & 8 & 1 & 1 & 46 & 2 & 2 & 0 & 0 \\
\hline China region & 850 & 86 & 86 & 60 & 60 & 403 & 18 & 18 & 6 & 6 \\
\hline Mekong region & 263 & 1 & 1 & 5 & 5 & 276 & 1 & 1 & 7 & 7 \\
\hline Indonesia region & 127 & - & - & 2 & 2 & 118 & - & - & 5 & 5 \\
\hline Japan & 87 & 20 & 20 & 5 & 5 & 77 & 12 & 12 & 3 & 3 \\
\hline Oceania & 17 & 1 & 1 & 0 & 0 & 22 & 0 & 0 & 1 & 1 \\
\hline Southern Asia & 253 & 9 & 9 & 1 & 1 & 363 & 27 & 27 & 6 & 6 \\
\hline $\begin{array}{l}\text { Rest Southern } \\
\text { Africa }\end{array}$ & 76 & 3 & 3 & 1 & 1 & 151 & 16 & 16 & 8 & 8 \\
\hline World & 4223 & 293 & 293 & 138 & 137 & 4493 & 231 & 231 & 145 & 145 \\
\hline
\end{tabular}

1 In this analysis only restrictions in utilization of these materials are availability and maximum additive content. It is assumed that the generated materials are of sufficient quality for use in blended cements. 
Appendix D. Clinker to cement ratios in 26 regions

See Figs. 9 and 10.

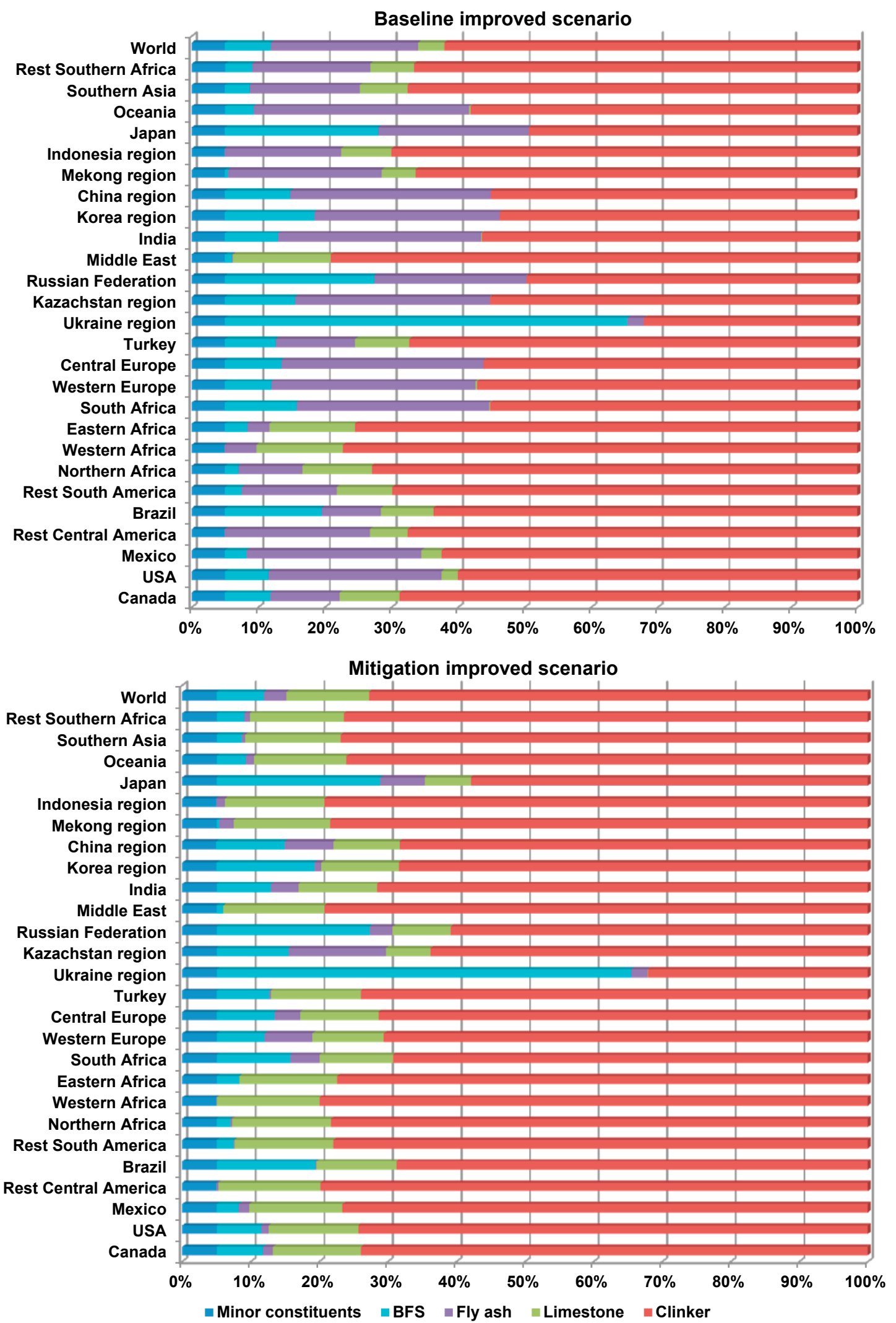

Fig. 9. Cement composition in 2050 under the (a) baseline improved and the (b) mitigation improved scenarios. 


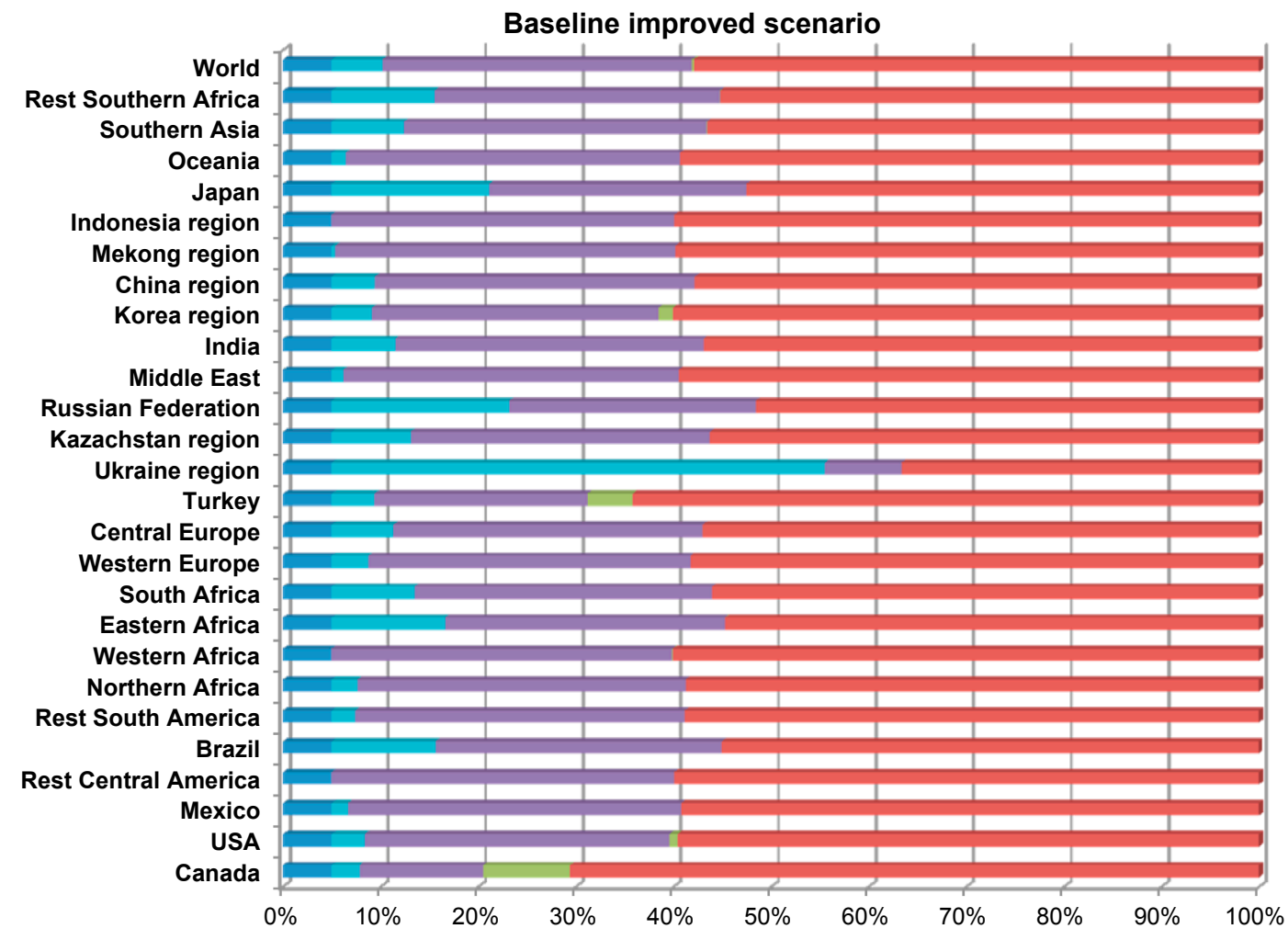

Mitigation improved scenario

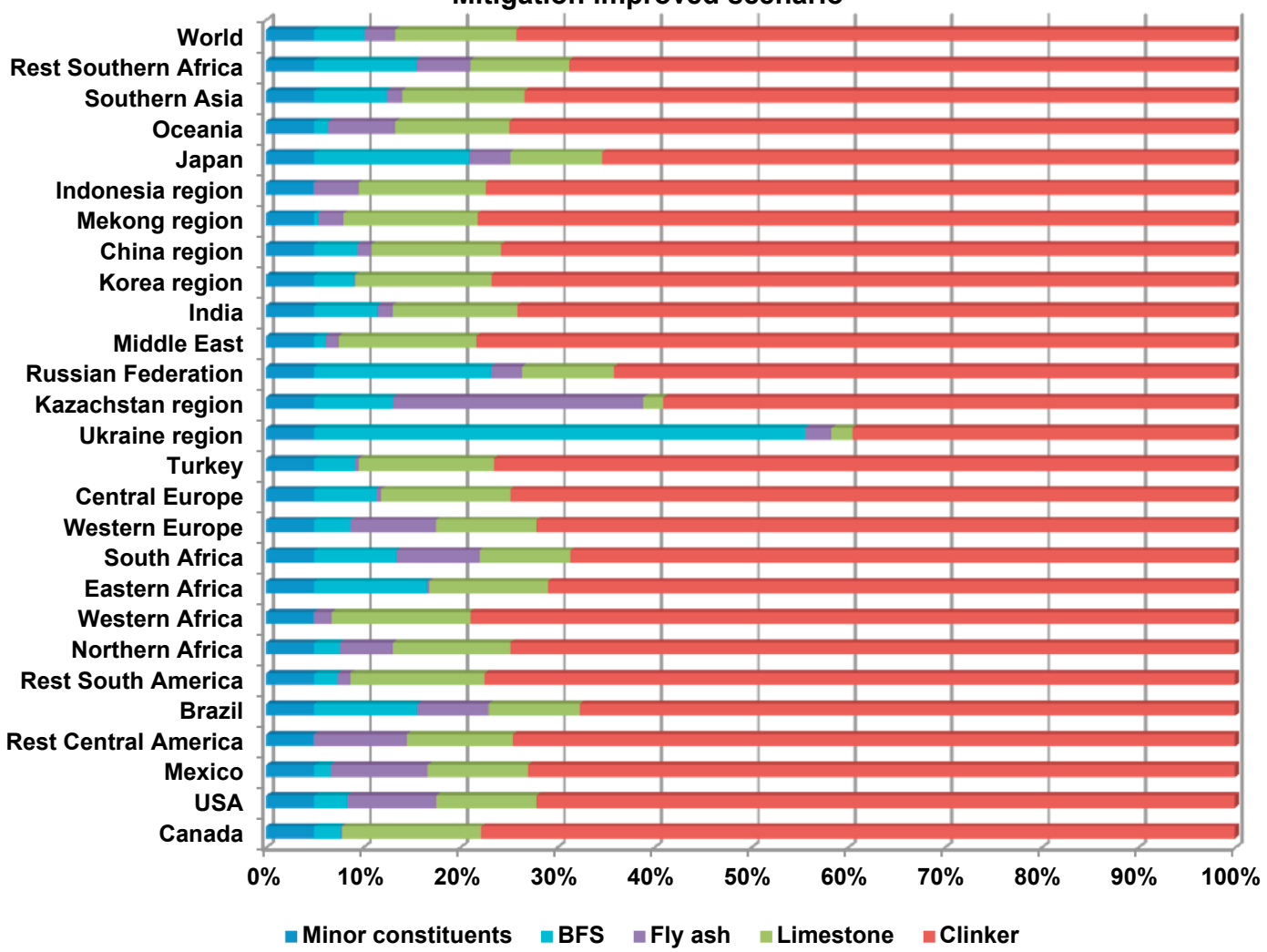

Fig. 10. Cement composition in 2100 under the (a) baseline improved and the (b) mitigation improved scenarios. 


\section{References}

[1] International Energy Agency (IEA). Energy technology perspectives 2017 Catalysing Energy Technology Transformations. Paris, France; 2017.

[2] International Energy Agency (IEA). World Energy Outlook 2014. Paris, France; 2014.

[3] Intergovernmental Panel on Climate Change (IPCC). Climate Change 2014: Mitigation of Climate Change. Contribution of Working Group III to the Fifth Assessment Report of the Intergovernmental Panel on Climate Change [Edenhofer O, Pichs-Madruga R, Sokona Y, Farahani E, Kadner S, Seyboth K, Adler A, Baum I, Brunner S, Eickemeier P, Kriemann B, Savolainen J, Schlömer S, von Stechow C, Zwickel T, Minx JC, editors.)]. Cambridge, United Kingdom and New York, NY, USA: Cambridge University Press; 2014.

[4] Global Energy Assessment (GEA) - Toward a Sustainable Future. Cambridge UK and New York, NY, USA: Cambridge University press and Luxemburg, Austria: the International Institute for Applied Systems Analysis; 2012.

[5] Sathaye J, Xu T, Galitsky C. Bottom-up representation of industrial energy efficiency technologies in Integrated Assessment Models for the cement industry. Ernest Orlando Berkeley National Laboratory (LBNL). LBNL-4395E; 2010.

[6] Rosen RA, Guenther E. The economics of mitigating climate change: What can we know? Technol Forecast Soc Chang 2015;91:93-106.

[7] Edelenbosch O, Kermeli K, Crijns-Graus W, Worrell E, Bibas R, Fais B, et al. Comparing projections of industrial energy demand and greenhouse gas emissions in long-term energy models. Energy 2017;122:701-10.

[8] Pauliuk S, Arvesen A, Stadler K, Hertwich EG. Industrial ecology in integrated assessment models. Nat Clim Chang 2017;7:13-20.

[9] Xu TT, Sathaye JA, Galitsky C. Development of bottom-up representation of industrial energy efficiency technologies in Integrated Assessment Models for the iron and steel sector. Ernest Orlando Lawrence Berkeley National Laboratory (LBNL). LBNL-4314E; 2010.

[10] Krey V. Global energy-climate scenarios and models: a review. WIREs Energy Environ 2014;3:363-83.

[11] Van Ruijven BJ, Van Vuuren DP, Boskaljon W, Neelis ML, Saygin D, Patel MK. Longterm model-based projections of energy use and $\mathrm{CO}_{2}$ emissions from the global steel and cement industries. Resources Conserv Recycl 2016;112:15-36.

[12] JRC/IPTS. Energy consumption and CO2 emissions from the world cement industry. Joint Research Centre; 2003.

[13] International Energy Agency (IEA). Tracking industrial energy efficiency and CO2 emissions. Paris, France; 2007.

[14] Akashi O, Hanaoka T, Matsuoka Y, Kainuma M. A projection for global $\mathrm{CO}_{2}$ emissions from the industrial sector through 2030 based on activity level and technology changes. Energy 2011;36:1855-67.

[15] Anand S, Vrat P, Dahiya RP. Application of a system dynamics approach for assessment and mitigation of $\mathrm{CO} 2$ emissions from the cement industry. J Environ Manage 2006;79:383-98.

[16] Pardo N, Moya JA, Mercier A. Prospective on the energy efficiency and CO2 emissions in the EU cement industry. Energy 2011;36(5):3244-54.

[17] Van Vuuren DP, Strengers BJ, De Vries HJM. Long-term perspectives on world metal use — a system dynamics model. Resour Policy 1999:25:239-55.

[18] Van der Werf E. Production functions for climate policy modeling: an empirical analysis. Energy Econ 2008;30:2964-79.

[19] Worrell E, Kermeli K, Galitsky C. Energy efficiency improvement and cost saving opportunities for cement making. United States Environmental Protection Agency (U.S. EPA); 2013.

[20] Kermeli K, Worrell E, Masanet E. Energy efficiency improvement and cost saving opportunities for the concrete industry. Ernest Orlando Lawrence Berkeley National Laboratory (LBNL); 2011.

[21] Boyd G, Zhang G. Measuring improvement in energy efficiency of the US cement industry with the ENERGY STAR Energy Performance Indicator. Energ Effic 2013;6(1):105-6.

[22] Worrell E, Biermans G. Move over! Stock turnover, retrofit and industrial energy efficiency. Energ Policy 2015;33(7):949-62.

[23] Department for Business, Energy \& Industrial Strategy (BEIS). Industrial gas prices in the IEA. United Kingdom; 2018. https://www.gov.uk/government/statisticaldata-sets/international-industrial-energy-prices.

[24] United States Geological Survey (USGS). Minerals Yearbook - Slag-Iron and Steel United States Geological Survey (USGS); 2002

[25] United States Geological Survey (USGS). 2013 Minerals Yearbook - Slag-Iron and Steel; 2015.

[26] Zeynel C. Review of 10th global slag Conference 2014. ZAG International; 2014 http://www.globalslag.com/conferences/.

[27] European Commission JRC-IPTS. IPPC Reference Document on Best Available Techniques (BREF) in the Cement, Lime and Magnesium Oxide Manufacturing Industries, May 2010; 2010. http://eippcb.jrc.ec.europa.eu/reference/.

[28] European Cement Research Academy (ECRA), Cement Sustainability Initiative (CSI). "Development of State of the Art - Techniques in Cement Manufacturing: Trying to Look Ahead". Düsseldorf, Germany; 2009.

[29] Oda J, Akimoto K, Tomoda T. Long-term global availability of steel scrap. Resour Conserv Recycl 2013;81:81-91.

[30] Pauliuk S, Milford RL, Müller DB, Allwood JM. The steel scrap age. Environ Sci Technol 2013:47(7):3448-54.

[31] Harder J. Development of clinker substitutes in the cement industry. ZKG International No.2/2006 (Volume 59), 2006. pp. 58-64.

[32] VDZ Research Institute of the Cement industry and PENTA Engineering Corp.,
Carbon Dioxide Control Technology Review, SN3001, Portland Cement Association (PCA), Skokie, Illinois USA; 2008.

[33] United States Geological Survey (USGS). 2013 Minerals Yearbook - Pumice and pumicite [Advance release]; 2015

[34] Kosmatka SH, Kerkhoff B, Panarese WC. Design and control of concrete mixtures. 14th ed. Portland: Cement Association (PCA); 2002.

[35] Koteswara RD, Pranav PRT, Anusha M. Stabilisation of expansive soil with rice husk ash, lime and gypsum - an experimental study. Int J Eng Sci Technol (IJEST) 2012;3:8076-85.

[36] Portland Cement Association (PCA). State-of-the-art report on use of limestone in cements at levels up to 15\%. Illinois, United States; 2014.

[37] Hoffman GK. Western region fly ash survey. In: Vories KC, Throgmorton D, editors. Proceedings of coal-combustion by-products and Western coal mines: a technical nteractive forum. Alton, IL: U.S. Department of the Interior, Office of Surface Mining; 2002.

[38] Fleiter T, Rehfeldt M, Herbst A, Elsland R, Klingler A-L, Manz P, et al. A methodology for bottom-up modelling of energy transitions in the industry sector: the FORECAST model. Energy Strategy Rev 2018;22:237-54.

[39] Herbst A, Fleiter T, Jochem E. Mutually linking bottom-up energy demand models with macroeconomic models: dealing with inter- and intra-sectoral structural change, Dague, South Korea: IAEE; 2013.

[40] Habert G. Assessing the environmental impact of conventional and "green" cement production. In: Pacheco-Torgal F, Cabeza LF, Labrincha J, de Magalháes A, editors. Eco-efficient construction and building materials. Woodhead Publishing Limited; 2014.

[41] Harder J. Outlook on the global cement and clinker trade. Buxtetehude, Germany; 2010.

[42] Kermeli K, Graus WHJ, Worrell E. Energy efficiency improvement potentials and a low energy demand scenario for the global industrial sector. Energ Effi 2014.

[43] World Business Council for Sustainable Development (WBCSD). GNR project reporting CO2; 2014. http://www.wbcsdcement.org/GNR-2012/index.html. Last visited $24 / 11 / 2014$;

[44] Xu J-H, Fleiter T, Eichhammer W, Fan Y. Energy consumption and $\mathrm{CO}_{2}$ emissions in China's cement industry: a perspective from LMDI decomposition analysis. Energy Policy 2012;50:821-32.

[45] Zhang S, Worrell E, Graus WC. Evaluating the co-benefit potentials of energy efficiency and emission mitigation in the China's cement industry. Appl Energy 2015; 147:192-213.

[46] Fujimori S, Masui T, Matsuoka Y. Development of a global computable general equilibrium model coupled with detailed energy end-use technology. Appl Energy 2014;128:296-306.

[47] Babiker MH, Reilly JM, Mayer M, Eckaus RS, Wing IS, Hyman RC. The MIT Emissions Prediction and Policy Analysis (EPPA) model: revisions, sensitivities, and comparisons of results. MIT Joint Program on the Science and Policy of Global Change. Boston, United States; 2001.

[48] EFDA. EFDA World TIMES Model, Final report, prepared by ORDECSYS, KanORS, HALOA, KUL; 2004. www.efda.org.

[49] ADVANCEwiki. ADVANCE Model description. http://themasites.pbl.nl/models/ advance/index.php/ADVANCE_wiki.

[50] Research Institute of Innovative Technology for the Earth (RITE). RITE GHG Mitigation Assessment Model; 2009.

[51] Yan D, Peng Z, Ding Q, Karstensen KH, Engelsen CJ, Li L, et al. Distribution of Hg, As and Se in material and flue gas streams from preheater-precalciner cement kilns and vertical shaft cement kilns in China. J Air Waste Manag Assoc 2015;65:1002-10.

[52] European Union. Evaluation of costs of the Russian cement industry's transition to BAT. Activity Cluster 1 National environmental harmonisation strategy, legal gap analysis. Moscow, Russia; 2009.

[53] Low Carbon Living CRC. State of practice: high volume applications of fly ash and barriers to commercialization. Research Project: RP1004-II. An Australian Government Initiative; 2012.

[54] International Energy Agency (IEA). IEA energy balances 2014. Paris, France: OECD/ IEA; 2015

[55] International Energy Agency (IEA). Energy statistics manual. Paris, France: OECD/ IEA; 2005.

[56] Statistics Canada (Statcan). Fuel consumed for electric power generation, by electric utility plants; 2016. www.statcan.gc.ca/.

[57] Association of Canadian Industries Recycling Coal Ash (CIRCA). Production and use of coal combustion products (CCPs). Production End Use Statistics; 2007.

[58] Lan W, Yuansheng C. The application and development of fly ash in China. 2007 World of Coal Ash (WOCA). May 7-10, 2007, Northern Kentucky, United states; 2007.

[59] Wang X, Deng J. Advances in utilization of flue gas desulphurization gypsum. In: 5 th international conference on advanced design and manufacturing engineering (ICADME, 2015); 2015

[60] European Coal Combustion Products in Europe (ECOBA). Valuable raw materials for the construction industry. Concrete Plant International (CPI) \#4, August 2006; 2006.

[61] Central Electricity Authority (CEA) New Delhi 2015. Report on fly ash generation a coal/lignite power stations and its utilization in the country for the year 2014-2015. New Delhi, India.

[62] Senapati MR. Fly ash from thermal power plants - waste management and over view. Curr Sci 2011;100(12)

[63] Dhadse S, Kumari P, Bhagia LJ. Fly ash characterization, utilization and Government initiatives in India - a review. J Sci Ind Res 2008;67:11-8. 
[64] Lokeshappa B, Dikshit AK. Disposal and management of fly ash. In: 2011 International conference on life science and technology. IPCBEE, vol. 3, Singapore; 2011.

[65] Moon STJD. Regulatory and legal applications: fly ash use in cement and cementitious products. In: 2013 World Coal Ash (WOCA), April 22-25, 2013, Northern Kentucky, United States; 2013.

[66] Ishikawa Y. Research on the quality distribution of JIS Type_II fly ash in Japan. 2007 World Coal Ash (WOCA), May 7-10, 2007, Northern Kentucky, United States; 2007.

[67] American Coal Ash Association (ACAA). 2011 Coal combustion product (CCP) production and use survey; 2012.

[68] Putilov VY, Putilova IV. Modern approach to the problem of utilization of fly ash and bottom ash from power plants in Russia. 2005 World Coal Ash (WOCA), April 11-15, 2005, Northern Kentucky, United States; 2005.

[69] Heidrich C, Feuerborn H-J, Weir A. Coal combustion products: a global perspective.
2013 World of Coal Ash (WOCA) Conference - April 22-25, Lexington (KY), United States; 2013.

[70] Worldsteel Association. Fact sheet - Steel industry by-products; 2014. http://www worldsteel.org/publications/fact-sheets/content/01/text_files/file/document/Fact_ By-products_2014.pdf.

[71] Fidjestøl P, Dåstøl M. The history of silica fume in concrete - from novelty to key ingredient in high performance concrete; 2008.

[72] United States Environmental Protection Agency (U.S. EPA). Alternative Control Techniques Document Update - NOx Emissions from New Cement Kilns. Control Technologies for the Cement Industry: Final Report, U.S. EPA, Washington, DC; 2007.

[73] World Business Council for Sustainable Development (WBCSD). The cement sustainability initiative - Cement industry energy and $\mathrm{CO} 2$ performance. Washington, 2009; 2009. 